\title{
Words Can Hurt: How Political Communication Can Change the Pace of an Epidemic *
}

\author{
Jessica Gagete-Miranda $^{\dagger}$ Lucas Argentieri Mariani ${ }^{\ddagger}$ Paula Rettl $\mathbb{\$}$
}

\begin{abstract}
Do cues from political elites influence their constituents' decisions about personal matters, such as health behavior? If so, why? Leveraging on a combination of natural and survey experiments, we study how President Bolsonaro's dismissive stance towards COVID-19 in Brazil influenced the b ehaviors and o pinions of $\mathrm{h}$ is o pponents and supporters. First, we exploit Bolsonaro's sudden display of skepticism towards COVID-19 in a differences-in-differences de sign. We show that municipalities with a concentration of his supporters witnessed higher mobility levels, excess hospitalization, and mortality in subsequent days. Second, results of two survey experiments indicate that these patterns are explained by Bolsonaro supporters following his cues and a backlash among his opponents. Heterogeneous exercises regarding participants' performance in a cognitive test and the strength of their political social identity provide evidence of the mechanisms. While heuristics drive the reaction of Bolsonaro opponents, willingness to comply with group norms explains the reactions of his supporters.
\end{abstract}

\footnotetext{
${ }^{*}$ We thank the valuable comments of Chris Anderson, Bert Bakker, Catherine De Vries, Francesco Granella, Selin Köksal, Paolo Pinotti, Marcos A. Rangel, Kenneth Scheve, Benedetta Scotti, Piero Stanig, and Steve Utych. The Editor and an anonymous referee from the CEPR's Covid Economics, Vetted, and Real-Time Papers series also provided valuable insights. This research was supported with funding from Bocconi PhD school. The usual caveats apply.

${ }^{\dagger}$ University of Milano-Bicocca

${ }_{\ddagger}^{\ddagger}$ Economic Research Southern Africa (ERSA) and University of Milano-Bicocca

$\S$ Bocconi University

I The authors' names appear in alphabetic order, indicating equal contribution. The pre-analysis plan of the survey experiments was registered before data collection started and can be found on the following link: https://osf.io/m9wnc/?view_ onl $y=2 b f 90 b 93064 a 47 b c b 81813 a 3 c 5362080$
} 


\section{Introduction}

An extensive body of scholarship investigates when and how political elites influence citizens' reasoning and opinions about politics (see Bullock, 2020, for a recent review). Because of the implications that such influence can have on accountability and responsiveness in democratic settings, the attention this topic has received is well deserved. On the one hand, party, candidate, and leader cues (henceforth, political elite cues) may help individuals make decisions consistent with their values and self-interests with very little effort (Lupia et al., 1998). On the other hand, if citizens blindly follow such cues, elected politicians can potentially engender the very opinions and evaluations to which they are supposed to be responsive and accountable (Bakker et al., 2020; Groenendyk, 2013; Lodge and Taber, 2013).

This debate becomes even more relevant if political elites influence opinions on highly salient and important issues that are more likely to influence electoral results (e.g., Slothuus and Bisgaard, 2021). A major determinant of issue importance is the extent to which individuals perceive it as directly influencing their lives. Issues involving personal matters are those that directly affect one's income, rights, lifestyle, or privileges (Apsler and Sears, 1968; Boninger et al., 1995; Mullinix, 2016). However, there are only few cases in which researchers have causally identified the effect of political elites' cues related to personal matters (e.g., Bisbee and Lee, 2021; Slothuus and Bisgaard, 2021).

At least two methodological challenges explain the lack of scholarship on this matter. First, decisions that involve personal matters are more credible in naturally occurring settings. However, longitudinal data on citizens' opinions or behaviors that spans before and after a party or political leader took or changed a position are rare (Slothuus and Bisgaard, 2021). Second, experimental studies tend to focus on issues of low salience because researchers consider that attitudes related to these issues are easier to manipulate (Arceneaux and Vander Wielen, 2017; Carsey and Layman, 2006; Groenendyk, 2013). This fact implies 
that most studies identify an upper bound of political elite cues' effects. ${ }^{1}$

In this paper, we analyze how and why Brazilians responded to President Bolsonaro's dismissive cues about the risks represented by COVID-19 (a virus that, although in different ways and magnitudes, affected everyone's life). To overcome the methodological challenges mentioned above, we leverage a combination of natural and survey experiments and conduct two studies. In our first study, we take advantage of the longitudinal and fine-grained availability of data on COVID-19-related behavior (i.e., social distancing) and its consequences (e.g., excess mortality) to analyze how Bolsonaro's supporters and opponents responded to his cues. More specifically, we exploit an arguably unexpected shift in President Bolsonaro's stance on social distancing that took place during country-wide demonstrations in a difference-in-differences design. By comparing municipalities with different levels of support for the President, we observe a divergence in trends of COVID-19 cases, hospitalizations, ICU occupation, and deaths starting a few days after the demonstrations. Moreover, by analyzing Google COVID-19 Community Mobility Reports data, we show a divergence in social distancing trends between pro- and against-Bolsonaro municipalities starting right after the demonstrations and persisting thereafter. These results are robust to a series of specifications, controls, and placebo tests.

In our second study, we overcome the ecological inference limitations of our first study and provide evidence of the why question. Because our first study relies on comparing aggregate data at the municipality level, we are unable to identify whether the cue effects we observe are driven by the persuasion of Bolsonaro's supporters or a backlash among his opponents. In fact, previous experimental studies in the US context show that leader cues may cause polarization between Republicans and Democrats not because in-groups follow their leader, but because out-groups take the opposite positions (Nicholson, 2012). Similarly, analyzing the effect of party cues in Brazil, Samuels and Zucco Jr (2014) and Samuels and Zucco (2018)

\footnotetext{
${ }^{1}$ Indeed, previous research relying on incentivized experiments shows that when individuals are rewarded for correct responses, the effect of party cues on opinion formation is smaller (Bullock, 2011; Prior et al., 2015).
} 
document the effect of party cues both on partisans and anti-partisans.

Another limitation of our first study is that it is unable to shed light on why people change their views regarding COVID-19 in response to Bolsonaro's cues. Previous research posits that individuals have two reasons to follow political elites' cues. First, individuals may follow cues to reduce effort in decision making, i.e., as a heuristics mechanism or shortcut (Lupia et al., 1998). Given that issues related to COVID-19 risks and prevention measures can be very complex and technical, it is likely that citizens will rely on heuristics to make up their minds about them. Second, individuals may follow cues as a way to comply with group norms and signal group membership. In other words, individuals gain utility from expressing their political identity (Bakker et al., 2020; Lodge and Taber, 2013). However, this type of motive tends to be stronger when the consequences of a decision are somewhat remote, as is the case with voting (Groenendyk, 2013). By contrast, deciding whether to wear a mask or practice social distancing has direct effects on one's life.

To overcome ecological inference issues and test which motives drive Bolsonaro supporters and opponents, we conducted two pre-registered survey experiments in Brazil. ${ }^{2}$ We randomly assigned Bolsonaro supporters and opponents to a control condition or Bolsonaro cue condition. In both conditions, respondents receive a short paragraph about how the scientific community perceives either the potential of a new and unapproved treatment for COVID-19 (experiment 1) or the need for practicing social distancing to protect oneself against COVID19 (experiment 2). In the control condition, participants were exposed to the opinion of "a Brazilian politician" about the matter at hand. In the treatment condition, we disclose that this opinion is Bolsonaro's. ${ }^{3}$ Our results show a polarizing effect of Bolsonaro's cues, with his supporters and opponents responding in opposite ways.

To distinguish between heuristics and expressive utility, we follow the approach by Bakker et al. (2020), who posit that the heuristics mechanism for cue-following implies that cues

\footnotetext{
${ }^{2}$ In our PAP (https://osf.io/m9wnc/?view_only=2bf90b93064a47bcb81813a3c5362080), we preregistered the hypotheses and related rationale, data pre-processing, regression specifications, and exploratory analysis.

${ }^{3}$ We do not engage in deception and our treatments are based on newspaper articles.
} 
should have smaller effects for individuals with high cognitive ability. By contrast, the expressive utility mechanism implies that individuals with strong political identity and higher cognitive ability should be the ones for which cue effects are the strongest. Heterogeneous treatment effects that consider participants' strength of political social identity and performance in a cognitive resource test (CRT) (all measured pre-treatment) show that while heuristics drive the reaction of Bolsonaro opponents to his cues, the willingness to comply with group norms drives the reactions of his supporters.

Overall, our contribution to the literature on party cues and, more generally, elite effects on political behavior ${ }^{4}$ is threefold. First, we show with a natural and a survey experiment that leader cues are powerful, even in one of the most unlikely political scenarios, i.e., when the decision at hand directly impacts individuals' lives and well-being (Groenendyk, 2013). Second, we provide evidence of the conditions under which different psychological mechanisms drive cue receptivity. Namely, our results suggest that heuristics and willingness to comply with group norms explain cue-receptivity among out-groups and in-groups, respectively. Third, we demonstrate that political social identity constructed around a political leader, as opposed to a party, has the potential to influence opinion and behaviors. We are able to show that because President Jair Bolsonaro did not belong to any party during the period we analyze. This finding is particularly relevant to scholars working on contexts where personalism is strong, such as in Latin America, Eastern Europe, and Southeast Asia and increasingly in Western Europe and the US (Frantz et al., 2021). Moreover, our research contributes to the growing body of literature, primarily focused on the US, that shows that partisanship shapes attitudes and behavior related to COVID-19 (e.g., Bisbee and Lee, 2021; Gadarian K. et al., 2022).

\footnotetext{
${ }^{4} \mathrm{~A}$ growing body of literature focuses on the effect of media and media bias on political behavior (e.g., Martin and Yurukoglu, 2017; Foos and Bischof, 2021).
} 


\section{Political elites' cues: moderators and mechanisms}

How and why political elites influence public opinion and behaviors are questions that directly affect the quality of the democratic processes. On the one hand, uninformed citizens might use political elites' cues as shortcuts to reach self-interest and value consistent opinions with reduced effort (Lupia et al., 1998). On the other, individuals strongly attached to their political identities may follow cues that are inconsistent with their self-interest and values in order to express group membership (Groenendyk, 2013; Lodge and Taber, 2013; Petersen et al., 2013). This debate becomes even more relevant when issues that have the potential to define electoral outcomes are concerned. This is the case with salient and important issues that have direct implications on individual lives (Slothuus and Bisgaard, 2021), such as those related to COVID-19 and related policies.

This paper aims to investigate how and why Brazilians responded to President Bolsonaro's cues about COVID-19. A vast literature investigates how political elites' cues influence public opinion, but also leaves a number of open questions. First, as Bullock (2020) points out, although party cue effects are well documented, their magnitude range from $3 \%$ to $43 \%$ of the scale on which attitudes or preferences are measured. Characteristics of the party systems, the sources of the cues, and informational environment partly explains such

variation. For example, the impact of party cues seems to be stronger in stable party systems, in which parties are easily distinguishable and political elites are polarized (Brader and Tucker, 2012; Druckman et al., 2013). In addition, cues by polarizing political figures may potentially provoke stronger effects than party cues because politicians represent less abstract entities than parties (Nicholson, 2012; Nisbett and Ross, 1980). While the literature has identified some moderators of elite cues, more research is needed to understand how much each of them counts and how they interact.

As we discuss in detail in the "Context" section, the case we analyze is characterized by a series of features that should reduce the power of political elites' cues. Indeed, the Brazilian party system is fluid and fragmented (Zucco et al., 2021), and most parties in the country 
are non-programmatic and hardly distinguishable (Samuels and Zucco, 2018). Hence, the characteristics of its party system make Brazil an unlikely context for political elite cues to influence public opinion (Samuels and Zucco Jr, 2014). However, President Bolsonaro is, arguably, a highly polarizing figure (Amaral, 2020), which can amplify cue effects (Nicholson, 2011).

Moreover, two main types of models explain why individuals react to political elites' cues: dual-processing and motivated reasoning. The dual-processing perspective posits that individuals process information either systematically or by relying on shortcuts (heuristics). When processing information systematically, individuals analyze the internal consistency of a message and compare it with what they know about the matter. Hence, systematic information processing requires high cognitive capacity and effort. Alternatively, individuals may rely on simple rules, such as source cues, to make decisions (Arceneaux and Vander Wielen, 2017; Kam, 2005; Lupia, 1994).

In turn, the motivated reasoning perspective contends that when individuals reason about a problem, they have two main motives in mind: an accuracy motive and a directional one. Accuracy motives prompt individuals to reach accurate conclusions and should be particularly strong when individuals have a personal stake involved in the decision. By contrast, directional motives lead individuals to reach conclusions that are consistent with their identity or prior beliefs (Groenendyk, 2013; Lodge and Taber, 2013). This perspective implies that cue-taking is driven by directional motives. Because reasoning to reach a specific conclusion requires individuals to engage in effortful thinking, this perspective implies that cue-following is stronger among individuals who are motivated to defend and rationalize their political views or identity, as well as have the incentives to do so (Bakker et al., 2020; Lodge and Taber, 2013; Petersen et al., 2013).

Both perspectives imply that when citizens reason about personal issues, such as whether practice social distancing, political elite cues should be less powerful. Indeed, opinions and behaviors related to COVID-19 prevention measures and treatments directly impact individ- 
ual lives by influencing their day to day habits and decisions. By contrast, political elites' cues should have a more powerful influence on opinions about more remote political issues that impact one's life only indirectly (e.g., macro-economic policy) (Groenendyk, 2013). According to the dual-processing perspective, we should expect that when issues involve personal matters, citizens will be more inclined to process information systematically. In turn, the motivated reasoning perspective predicts that in such contexts, accuracy motives will prevail.

Nevertheless, the two perspectives yield different predictions in regards to which individuals are more likely to be influenced by political elite cues in any issue environment. The dual-processing perspective implies that cue-receptivity will be higher among individuals with limited cognitive resources and who are therefore less able to process information systematically. By contrast, the motivated reasoning perspective entails that cue-receptivity is a function of motivation to follow the cue (in this case, the strength of political social identity) and the capacity to rationalize and justify opinion change (which can be measured by the level of cognitive resources) (Bakker et al., 2020). Under which conditions each of these perspectives better explains the effects of political elites' cues on opinions and behaviors is an unsettled debate (Arceneaux and Vander Wielen, 2017; Bakker et al., 2020; Bullock, 2020). In our second study, we analyze which of these two perspectives is driving cue-receptivity in the case we analyze.

\section{Context}

Two main factors make Brazil an unlikely case for party identification to shape attitudes and behavior (Samuels and Zucco Jr, 2014). First, Brazil is a young democracy where the party system is highly unstable and fractionalized (Zucco et al., 2021). Moreover, the open-

list system for legislative elections weakens party labels and enhances the importance of individual politicians (Ames, 2001; Samuels, 2003). These factors make it hard for voters to 
identify what each party stands for. Second, when social cleavages map into partisanship, party attachments tend to be stronger and more stable (Campbell et al., 1980; Lipset and Rokkan, 1967). However, historically in Brazil, this has not been the case (Mainwaring and Scully, 1995). Yet party cues still shape attitudes of partisans and anti-partisans in Brazil, especially if the source of the cue is one of the two most competitive parties in presidential elections since re-democratization: the Worker's Party (Partido dos Trabalhadores, PT) and the Brazilian Social Democracy Party (Partido da Social Democracia Brasileira, PSDB) (Samuels and Zucco Jr, 2014; Samuels and Zucco, 2018).

However, Bolsonaro's election in 2018 challenged the centrality of dispute between the PT and the PSDB in presidential elections. Bolsonaro was neither a member of the PT nor of the PSDB. Instead, he ran under the label of a small party that he had joined for the purposes of running for president in 2018: the Social Liberal Party (Partido Social Liberal, PSL). Eleven months into his first year in the presidency, Bolsonaro exited this party and only joined another one in December 2021, in anticipation of the 2022 Presidential election. ${ }^{5}$ Therefore, by the time the first COVID-19 case was identified on February 26, 2020, Bolsonaro had no party. This fact allows us to confidently interpret our results as the effect of his cues alone and not as a combined effect of leader and party cues.

Moreover, the identification strategy of our first study relies on a sudden change in Bolsonaro's public stance towards COVID-19. At the beginning of the health crisis in February 2020, the President sent mixed signals on the risks associated with COVID-19. On March 10, he said that the "destruction potential" of COVID-19 was being overestimated. Two days later, he declared that the Brazilian health system has a limited capacity to treat patients and that the government was paying attention to and monitoring the evolution of COVID-19 in the country. At that time, about four hundred people had tested positive in the country (Folha de São Paulo, 2021).

On March 15, organized street demonstrations took place in about two hundred and fifty

\footnotetext{
${ }^{5}$ In Brazil, candidates must be registered into a party to run any type of election.
} 
municipalities. In a move that surprised the media, the public, and the health minister, President Bolsonaro joined the protests in Brasília, the country's capital, to meet, greet, and shake hands with demonstrators. On this day, the President himself was supposed to be self-isolating since he had been exposed to staff members who had tested positive for COVID-19 (Marshall, 2020). After March 15, President Bolsonaro decidedly shifted his attitudes towards COVID-19. His discourse became consistently dismissive towards social distancing measures and mask-wearing. ${ }^{6}$

\section{Study 1: Evidence from a natural experiment}

To estimate the impact of President Bolsonaro's cues on COVID-19-related behavior, we assemble data from different sources for virtually all Brazilian Municipalities. ${ }^{7}$ We use this data in a difference-in-differences design that exploits Bolsonaro's change in position regarding the risks represented by COVID-19 during the country-wide demonstrations that took place in early days of the pandemic in Brazil.

\section{Measuring social distancing and COVID-19 prevalence}

We use four different indicators to measure the pace of the epidemic diffusion in Brazil. First, we use data on COVID-19 cases from daily reports of the State Health Secretariats. $^{8}$ A drawback of this measure is that the official number of COVID-19 cases is underreported. While this applies to all countries that did not test a random sample of the population, underreporting in Brazil is particularly problematic (de Souza et al., 2020). ${ }^{9}$

To address this concern, we use data on excess mortality, hospitalization, and admission to ICU due to flu-like illness, by date and municipality of residence. Individuals in Brazil

\footnotetext{
${ }^{6}$ A timeline of Bolsonaro's declarations and measures on COVID-19 was constructed by (Rosa et al., 2020) (in Portuguese).

${ }^{7}$ Our sample comprises 4,887 municipalities out of 5,570 .

${ }^{8}$ This information was compiled by Cota (2021) and Justen (2022)

${ }^{9}$ Based on two seroprevalence surveys conducted in May and June 2020, Hallal et al. (2020) estimate that only one in ten COVID-19 cases and deaths were officially reported as such in Brazil.
} 
necessarily vote in their municipality of residence but might be hospitalized, admitted to ICU, or die in a different municipality than the one where they usually reside. Thus, for our purposes, using the municipality of residence is more appropriate. These data come from the Influenza Epidemiological Surveillance Information System (Sistema de Informação de Vigilância Epidemiológica da Gripe), which is managed by the Brazilian Secretariat of Health Surveillance (InfoGripe). It collects information from detailed reports filled out in all hospitals in the country about patients with flu-like illnesses. This database includes anyone who shows up at a public or private hospital with fever and cough or sore throat and at least one of the following symptoms: shortness of breath, oxygen saturation below $95 \%$, or respiratory distress. These symptoms are typical of SARS-CoV-2 (Huang et al., 2020; de Souza et al., 2020). Moreover, the database includes information about people who died with these symptoms, whether they were hospitalized or not. We use data ranging from the beginning of 2014 to mid-April $2020 .^{10}$

These measures have the advantage of being accurate in terms of time and geography. We have information about the exact day that a new hospitalization, admission to ICU, or death due to flu-like illness occurred. Also, since hospitals collect information on each patient's municipality of residence, we can measure the prevalence of COVID-19, even in places where no hospitals exist. This is important for comparisons across space in a relatively short time. In contrast, differences in the number of cases are not as accurate because testing results are usually released days after exposure to the contagion, and testing capacity varies across municipalities.

While we can be sure about the number of hospitalizations, admission into ICU, and deaths due to flu-like illness in a given municipality and day, the same cannot be said about whether COVID-19 indeed caused them. In fact, other respiratory viruses were circulating in the country in the period we analyze (de Souza et al., 2020). This is a common issue in

\footnotetext{
${ }^{10}$ One of the aims of this database is to provide nearly real-time information about epidemics linked to flu-like diseases. The data we used in this manuscript was deemed stable by the time we downloaded it (between 28 and 31 July 2020).
} 
the literature that analyzes the impact of shocks - such as extreme temperatures - on health outcomes, particularly on mortality (e.g., Toulemon and Barbieri, 2008; Heutel et al., 2020).

A widely accepted way to address this issue is to compute excess mortality, which is meant to capture the "exceptional" number of deaths that occur in a specific time interval compared to a reference point. Excess mortality has been used to compare the impact of COVID-19 on subnational regions (e.g., Zhou et al., 2021) as well as to quantify the effectiveness of non-pharmaceutical interventions in controlling the COVID-19 epidemic (Basellini et al., 2020). Based on previous literature, we define excess mortality as the difference between the cumulative number of deaths in a municipality $m$ between January 1, 2020, and day $t$, and the average cumulative death in municipality $m$ between January 1 and day $t$ of the five previous years (i.e., 2015 to 2019). ${ }^{11}$ We then extend this same measure to the number of hospitalizations and admissions to ICU (henceforth excess hospitalization and excess ICU).

Once infected by COVID-19, most people will not develop strong symptoms. Hence, the majority of those infected by COVID-19 are unlikely to look for a hospital. Furthermore, the estimated incubation period of COVID-19 is from 2 to 14 days (mean of around 5 days). Moreover, the estimated mean time from illness onset to hospital admission is estimated to be 3 to 4 days. Nevertheless, in some cases, clinical conditions deteriorate quickly, and a small share of individuals die within a week of symptoms onset (Linton et al., 2020; Verity et al., 2020).

To test whether social distancing is a mechanism in place, we use the Community Mobility Reports released by Google for 133 countries. These reports are created with anonymized data from users' mobile devices aggregated at the municipal level. These data contain six measures of social distancing, namely visits to retail and recreation, grocery and pharmacy, parks, public transportation, and workplaces, as well as staying in one's residential area. As the data is anonymized, Google does not make it available if the number of users is below a certain threshold. This is especially true for smaller municipalities during the weekends,

\footnotetext{
${ }^{11}$ Formally, let $t$ denote the day of the year: Excess mortality ${ }_{m, t, 2020}=\sum_{i=\operatorname{Jan} 1,2020}^{t}$ deaths $_{m, i}-$ $\frac{1}{5} \sum_{y=2015}^{2019} \sum_{i=J a n 1, y}^{t}$ deaths $_{m, i}$.
} 
and for certain types of places that do not have a high number of users. ${ }^{12}$ Keeping these shortcomings in mind, we focus on the two variables that register the least amount of missing data: visits to workplaces and staying in one's residential area during weekdays. We ignore municipalities with missing data. ${ }^{13}$ Google calculates these measures as deviations from their daily median value from the five weeks between Jan 3 and Feb 6, 2020, and reported such deviations in percentage points.

\section{Other data sources and measures}

We use the 2018 Presidential election results to measure support for President Bolsonaro in a given municipality. ${ }^{14}$ Brazilian Presidential elections are run under a dual-ballot system. For each municipality, we use the first-round results to define support for President Bolsonaro. Results from the first round are preferable because in multi-party systems (such as in Brazil), individuals tend to vote more sincerely in first rounds than in runoffs (Fujiwara et al., 2011). We measure support at the municipality level as a binary variable that equals one if the thencandidate Jair Bolsonaro received the majority of valid votes in the first round; otherwise, it is 0 . As shown in Table A.1, this is the case for $53 \%$ of the municipalities in our sample. We choose to measure support for the president as a binary variable because it makes the interpretation of the dynamic effects easier. However, in the Online Appendix, we present the results by deciles of support for the president.

In some of our specifications, we also use the most recent Demographic Census data available (from 2010) to measure the share of individuals older than 60, of illiterate people (a proxy for education), and of women at the municipality level. In addition, we gather data on municipalities' area (in $\mathrm{km}^{2}$ ) and population in 2018 (the most recent release) from the

\footnotetext{
${ }^{12}$ For more details about these issues, see Google (2022).

${ }^{13}$ Missing data in this context is a signal of a low number of users, therefore lower mobility. Using the municipalities with missing data would, therefore, severely bias our results. Our final balanced panel for these specific measures comprises 415 municipalities. The results from a balanced panel in all the Google Community Mobility Reports variables, with 215 municipalities, align with the results here and are available upon request.

${ }^{14}$ Electoral results at the municipal level come from Superior Electoral Court (Tribunal Superior Eleitoral, in Portuguese).
} 
Brazilian Bureau of Statistics (Instituto Brasileiro de Geografia e Estatística). Moreover, we leverage data on the location of March $15^{\text {th }}$ demonstrations from a document circulated by the organizers ("Movimento Avança Brasil") listing all the municipalities where protests were confirmed to happen. ${ }^{15}$

\section{Identification Strategy}

We exploit the facts described in the section "Context" to estimate the impact of President Bolsonaro's cues on the spread of COVID-19. More specifically, we identify the day of the demonstrations (i.e. March $15^{\text {th }}$ ), when the President joined the masses to greet his supporters, as a marked change in his public stance towards the risk represented by COVID-19. Therefore, we analyze trends in COVID-19 cases around this date, comparing municipalities with higher and lower support for President Bolsonaro. The idea behind this strategy is that pro-Bolsonaro municipalities respond to his cues differently than anti-Bolsonaro municipalities.

We focus on March $15^{\text {th }}$ as opposed to considering the later dates in which President Bolsonaro sent dismissive messages about COVID-19 for methodological reasons. Specifically, if the behavior of the President on March 15 had an effect on social distancing, we can no longer assume parallel trends between pro- and anti- Bolsonaro municipalities after this day. Thus, our identification strategy is a difference-in-differences design, described by the following estimation:

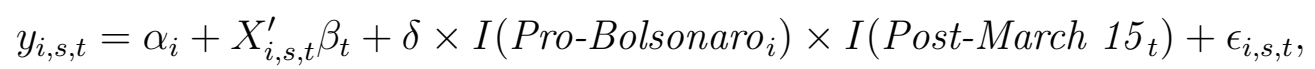

where $y_{i, s, t}$ is the measure of COVID-19 incidence (number of cases, excess hospitalization, excess ICU, and excess death) in municipality $i$, in commuting zone $s$, on day $t \cdot{ }^{16}$ To

\footnotetext{
${ }^{15}$ For the complete list of municipalities where protests tool place see Gazeta do Povo (2020). Out of the 257 municipalities listed in this document, 236 are included in our specification.

${ }^{16}$ The Brazilian Institute of Geography and Statistics (Instituto Brasileiro de Geografia e Estatistica, IBGE) commuting zones are aggregations of cities around a common regional center (usually a metropolis).
} 
make municipalities comparable, we control for time-varying unobserved heterogeneity, such as trends among municipalities with similar characteristics. Due to the highly contagious nature of COVID-19, it is important to consider both population density and individuals' movements across municipalities to account for local spillovers. Hence, besides controlling our estimations for municipality fixed effects, $\alpha_{i}$, we also control them for common trends in municipalities with similar population density and within the same commuting zones. We do this by adding vector $X_{i, s, t}$, which controls for time trends interacted with population density and commuting zones. The latter also absorbs the effect of non-pharmaceutical measures implemented by governors. ${ }^{17}$ Moreover, vector $X_{i, s, t}$ also controls for interactions between time trends and the number of cases on March 14. This absorbs common trends among municipalities with the same initial number of infected people. We cluster the standard errors of our estimations by municipality level to account for autocorrelation across time, and by commuting zone $\times$ time FE level to account for spatial correlations among municipalities.

Our parameter of interest is $\delta$. The variable "Pro-Bolsonaro" is defined as a binary variable indicating that Bolsonaro had the majority of votes in a municipality in the first round of the 2018 presidential election. The variable "Post-March 15" is a binary variable equal to one after March 15 and zero otherwise. We use the inverse hyperbolic sine transformation of our dependent variables in Equation 1. Thus, $\delta$ can be interpreted as the difference in percentage of the growth in the number of cases in municipalities with higher support for President Bolsonaro after the demonstrations on March $15 .^{18}$

The validity of this identification relies on the assumption that Bolsonaro supporters were not able to learn about his attitude towards COVID-19 before the protests on March 15. The fact that the President sent mixed signals about COVID-19 before the demonstrations reinforces this argument. Still, we test this assumption by looking at the dynamic effects of

\footnotetext{
${ }^{17}$ The roll-out of shelter-in-place mandates was staggered, with states restricting physical movement at different times. Our sample includes all states, as shown in Figure A.1, in the Online Appendix.

${ }^{18}$ The inverse hyperbolic sine transformation is defined as $\ln \left(x+\sqrt{1+x^{2}}\right)$ and is a standard transformation in the literature in cases when there are many zeros and negative values (see Bellemare and Wichman, 2020).
} 
Bolsonaro's cues before and after March 15. We implement the following specification:

$$
y_{i, s, t}=\alpha_{i}+X_{i}^{\prime} \beta_{t}+\sum_{k=-15}^{31} \delta_{k} \times I\left(\text { Pro-Bolsonaro }_{i}\right) \times I\left(\text { Post-March }_{15}\right)+\epsilon_{i, s, t}
$$

, where $I$ (Post-March $\left.15_{k}\right)$ is a binary variable indicating the $k^{t h}$ day after the demonstrations. We look at a window of fifteen days before and a month after March 15 .

\section{Results}

Table 1 presents the results of our main estimation using the specification in Equation (1). Column (1) presents the results for confirmed COVID-19 cases while columns (2), (3), and (4) present the results for excess hospitalization, ICU use, and death due to flu-like disease, respectively. The results show that after March 15, municipalities in which the President has greater support had a higher prevalence of COVID-19. More specifically, proBolsonaro municipalities experienced a number of COVID-19 cases $16.2 \%$ higher relative to anti-Bolsonaro municipalities. Similarly, pro-Bolsonaro municipalities also had higher excess hospitalization, admission to ICU, and deaths $(22.0 \%, 13.1 \%$, and $8.2 \%$, respectively). In the Online Appendix, we report the results by decile of support for the President. Overall, the magnitude of the results increase with the support for the President.

\begin{tabular}{lcccc}
\hline \hline & $(1)$ & $(2)$ & $(3)$ & $(4)$ \\
& Confirmed cases & Excess hospitalization & Excess ICU & Excess death \\
\hline Post March 15 × Pro-Bolsonaro & $0.162^{* * *}$ & $0.220^{* * *}$ & $0.131^{* * *}$ & $0.082^{* * *}$ \\
& $(0.025)$ & $(0.035)$ & $(0.025)$ & $(0.019)$ \\
\hline Observations & 224,342 & 224,342 & 224,342 & 224,342 \\
R Squared & 0.69 & 0.85 & 0.84 & 0.73 \\
Municipality FE & $\checkmark$ & $\checkmark$ & $\checkmark$ & $\checkmark$ \\
Commuting zone x Time FE & $\checkmark$ & $\checkmark$ & $\checkmark$ & $\checkmark$ \\
Pre-demo number of cases x Time FE & $\checkmark$ & $\checkmark$ & $\checkmark$ & $\checkmark$ \\
Population Density x Time FE & $\checkmark$ & $\checkmark$ & $\checkmark$ & $\checkmark$ \\
\hline \hline Notes: (i) Standard errors clustered at municipality level and commuting zone x Time FE level; (ii) ${ }^{*}$ p $<0.10,{ }^{*}$ p $<0.05, * *$ \\
p<0.01; (iii) Each dependent variable in this table is the Inverse Hyperbolic Sine Transformation of the original variable.; \\
(iv) On March 15 Bolsonaro supporters marched against the Congress and Bolsonaro ignored coronavirus warnings to join \\
them; (v) Estimations based on a sample of 4,887 municipalities.
\end{tabular}

Table 1: Disproportional Growth in COVID-19 spread on Pro-Bolsonaro municipalities after demonstrations on March 15 
Figure 1 shows the dynamic results coming from Equation 2 for our variables related to COVID-19 spread. It shows that pro- and against-Bolsonaro municipalities have the same incidence of COVID-19 before the demonstrations and also for a few days after. More precisely, the trends of COVID-19 cases, excess hospitalization, admission into ICU and deaths in pro- and against-Bolsonaro municipalities become statistically different at $5 \%$ confidence level on March 23, 18, 21 and 24, respectively. Moreover, ten days after the demonstrations (i.e., by March 25), all the measures of COVID-19 diffusion are persistently higher in pro-Bolsonaro municipalities. Overall, this is in line with the clinical characteristics of the disease. ${ }^{19}$ Importantly, our estimates indicate that the effect on cases occurs after the effect on hospitalizations. This is most likely due to the fact that while hospitalizations, ICU occupation and excess deaths are registered in real time, cases are reported with significant delay (see section "Measuring social distancing and COVID-19 prevalence" for more details).

We perform a similar specification in Figure 2 with the Google Community Mobility Reports data for workplaces and residential places to check if the divergence in the COVID-19 spread presented in Figure 1 was due to changes in mobility after the demonstrations on March $15^{\text {th }} .^{20}$ To do that, we run estimations on the balanced sample of municipalities without missing information on these two mobility measures produced by Google. The results, displayed in Figure 2a, show a decrease in social isolation right after the demonstrations measured by the mobility in workplaces. This implies that the effect of the President's cues on social isolation is observed immediately after the demonstrations, and the effect persists

\footnotetext{
${ }^{19}$ As we point out in section "Measuring social distancing and COVID-19 prevalence", the estimated incubation period of COVID-19 is from two to 14 days. Moreover, the estimated mean time from the symptoms onset to hospitalization if 3-4 days. However, clinical conditions may deteriorate faster for some individuals (Linton et al., 2020; Verity et al., 2020).

${ }^{20}$ Our analysis complements a paper by Ajzenman et al. (2021) showing that compliance with social distancing was lower in pro-Bolsonaro municipalities after the President's dismissive declarations. We complement this work by showing that this is also the case for different measures of compliance with social distancing, namely traveling to work and shelter in place, and that such a decrease in isolation increased COVID-19 incidence in pro-Bolsonaro municipalities. Moreover, to the best of our knowledge, we are the first to investigate the mechanisms behind such change in behavior. Namely, we show that Bolsonaro supporters react to the President's cues in a cue-consistent way in order to express their political social identity, and, in turn, Bolsonaro opponents use his cues as a shortcut and update their beliefs in the opposite direction of the cue.
} 


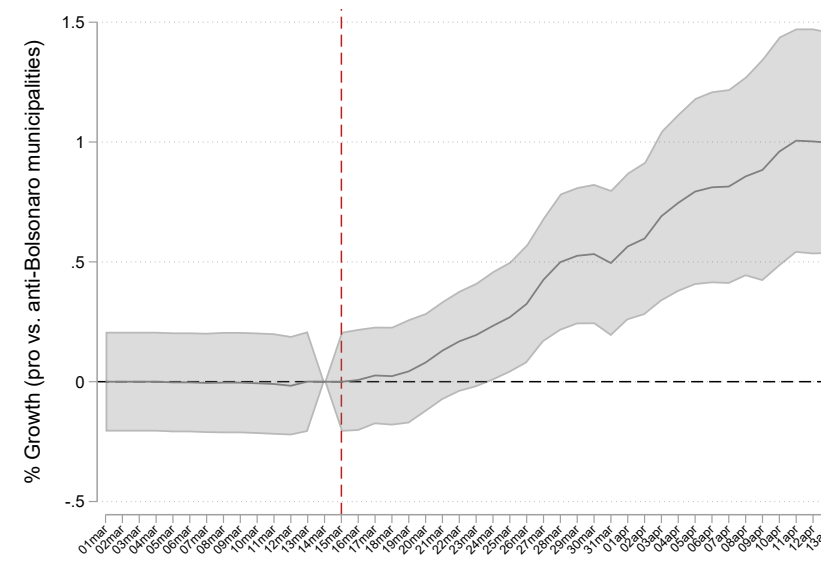

(a) Number of cases

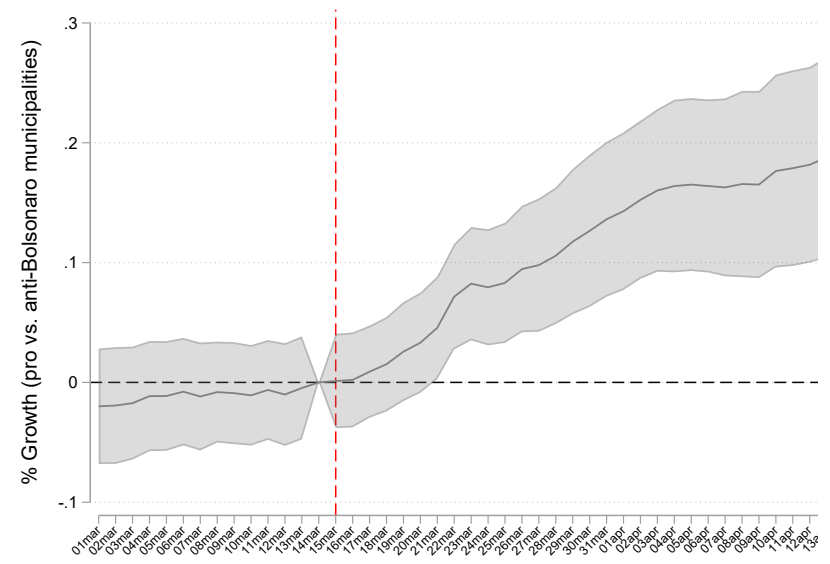

(c) Excess ICU

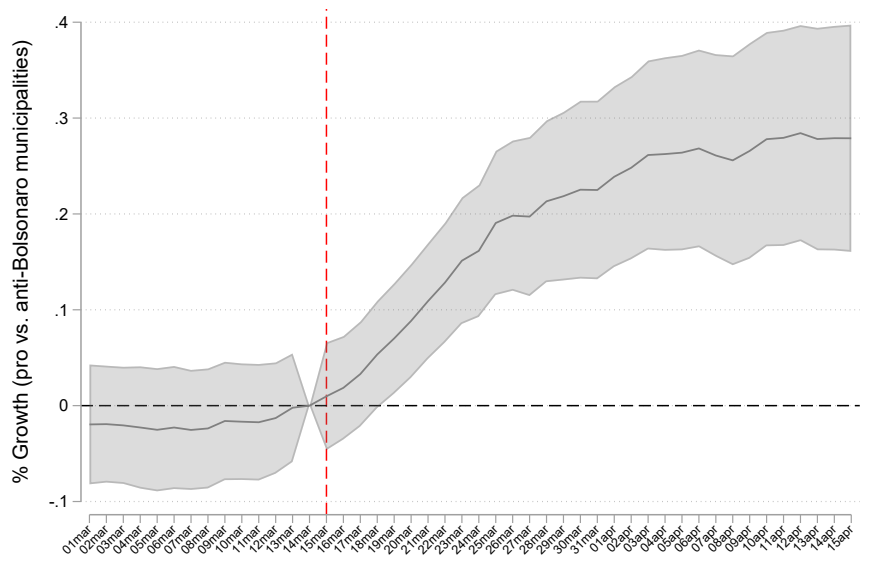

(b) Excess of Hospitalization

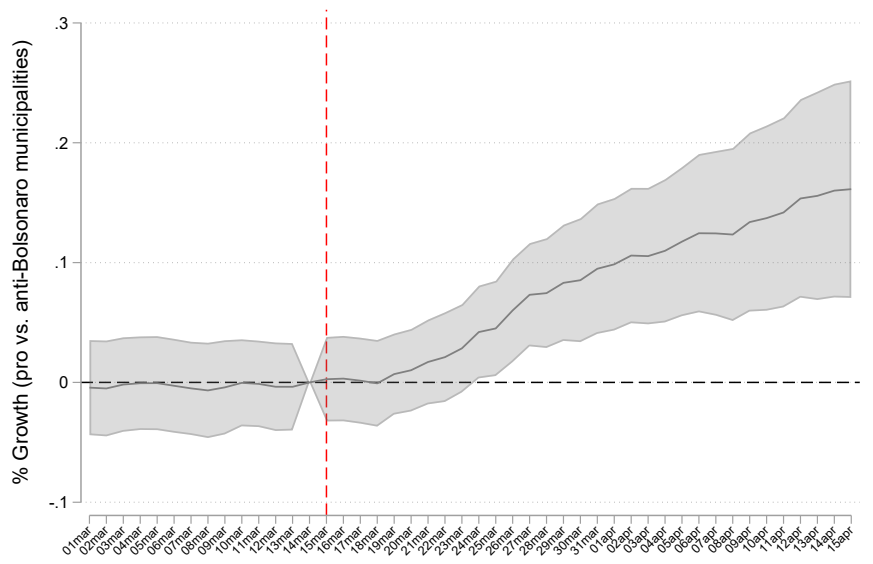

(d) Excess of Deaths

Figure 1: Disproportional COVID-19 spread on Pro-Bolsonaro municipalities

Notes: (i) Reported 95\% confidence intervals are based on standard-errors clustered at municipality level and commuting zone $\mathrm{x}$ Time FE level, (ii) Dashed line indicates the demonstrations on March 15. (iii) Regression controls for time interactions with population density, number of cases before the demonstrations, and fixed-effects for commuting zone-date and municipality; (iv) Estimations based on a sample of 4,887 municipalities.

until at least one month after the event. When we look at the effects on mobility in residential places, we see that Pro-Bolsonaro municipalities started to diverge and stayed less at home after the demonstrations. However, these effects only became statistically significant on April $2^{\text {nd }}$. Altogether, our results provide evidence that cities with more and fewer supporters of the President started to behave differently in terms of social isolation and mobility after the demonstrations. 


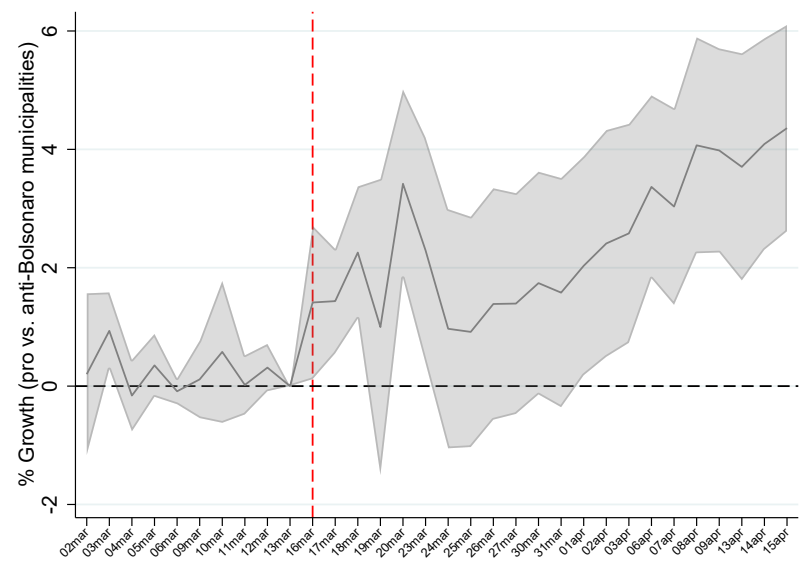

(a) Mobility - Workplaces

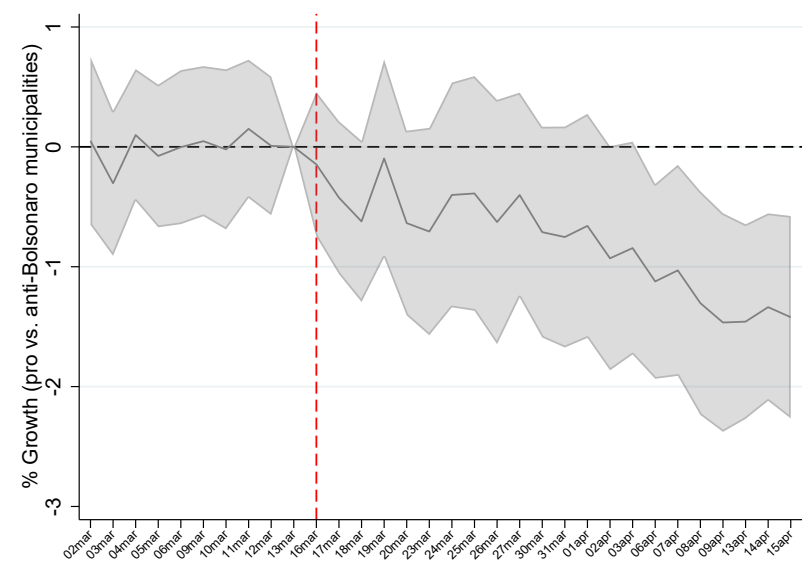

(b) Mobility - Residential Places

Figure 2: Disproportional Changes in Mobility

Notes: (i) Data source:Google Community Mobility Reports (ii) Reported 95\% confidence intervals are based on standard-errors clustered at municipality level and commuting zone x Time FE level; (iii) Dashed line indicates the demonstrations on March 15 . (iv) Regression controls for time interactions with population density, number of cases before the demonstrations, and fixed-effects for state-date. (v) The first week of March is the baseline value in this specification; (vi) Estimations based on a sample of 415 municipalities.

\section{Robustness checks}

These results are robust for a number of checks. First, as shown in Table A.1 in the Online Appendix, pro- and anti-Bolsoaro municipalities were at different stages of COVID-19 spread before the demonstrations. The excess of hospitalization, ICU use, and mortality due to flulike symptoms were higher in pro-Bolsonaro municipalities already on March 1. This is probably driven by the fact that our sample contains municipalities that did not have a single case of COVID-19 in the time-frame analyzed and most of the municipalities with zero cases within this time-frame are anti-Bolsonaro municipalities. This problem is not too worrisome since we observe in Figure 1 common trends in the spread of COVID-19 before the demonstrations, but we nevertheless check whether the results displayed in Table 1 hold for a more comparable sample of municipalities. Therefore, we restrict our sample to municipalities that had at least one COVID-19 case before April 15. As presented in Table A.3 in the Online Appendix, pro- and anti-Bolsonaro municipalities in this sub-sample were at the same stage of the spread of COVID-19 and hence are more comparable. Table A.4 in the Online Appendix reproduces the estimations from Table 1 for this sub-sample, and we can see that, if anything, the results are of greater magnitude than the results for the whole 
sample.

Second, as shown in Table A.1 in the Online Appendix, pro-Bolsonaro municipalities are different than anti-Bolsonaro municipalities in several characteristics that might affect the spread of COVID-19. Pro-Bolsonaro municipalities have a higher population density and size, a higher share of the elderly, and a lower share of illiterate individuals. All our estimations include municipality fixed effects to control for such differences. Still, Table A.5 in the Online Appendix presents estimations controlling for other non-linear trends. In column (1), we control the estimations for trends in municipalities within the same quartile in the population distribution; in columns (2), (3), and (4), we control for trends in municipalities within the same quartile of the distributions of the elderly population (people older than 60), women, and illiterates, respectively; finally, in column (5), we control for trends in municipalities within the same quartile of the GDP per capita distribution. Again, the results are fairly consistent throughout all estimations and for all measures of COVID-19 spread.

Moreover, there are at least two other possible confounders of the results presented above. First, pre-existing characteristics of Bolsonaro supporters might be correlated with compliance with non-pharmaceutical interventions. One example of such characteristics is trust in institutions. Second, agglomerations during the demonstrations that took place on March 15 might have been more common in municipalities that concentrate Bolsonaro supporters. In turn, gatherings during the demonstrations might have caused an increase in COVID-19 transmissions.

To address the first concern, we analyze the effects of the $2019 \mathrm{flu}$ vaccination campaigns. $^{21}$ If voters' pre-existing characteristics are the main drivers of our results, we should expect that President Bolsonaro's supporters comply less with the vaccination campaign even in the absence of leader cues. Hence, vaccination take-up should be smaller in pro-Bolsonaro municipalities when compared to anti-Bolsonaro municipalities. If this is the case, we should

\footnotetext{
${ }^{21}$ This is a known public health policy that has encountered problems with compliance in many countries (e.g., Chen and Toxvaerd, 2014).
} 
also observe higher levels of hospitalization, admissions to ICU, and deaths due to flu-like illnesses during the influenza peak season in 2019 in pro-Bolsonaro municipalities. In the Online Appendix, we show that this is not the case, suggesting that pre-existing characteristics between Bolsonaro supporters and opponents are unlikely to be the driving force behind our results.

We then run a series of regressions to address the second concern, namely that gatherings during the demonstrations are driving our results. Table A.2 presents exercises that take into account possible impacts coming directly from the demonstrations. In the first exercise (columns (1), (3), (5), and (7)), we control for common trends among municipalities that hosted demonstrations on March 15. In the second exercise (columns (2), (4), (6), and (8)), we estimate the same specification with a restricted sample in which we include only the municipalities where pro-government demonstrations did not take place on March $15 .^{22}$

If agglomeration during the demonstrations was the only driver of the faster spread of COVID-19 observed in pro-Bolsonaro municipalities after March 15, the results would vanish when controlling for their presence or restricting the sample to localities where they were absent. However, the results persist in both cases. This provides further evidence that our results are driven by Bolsonaro's cues. ${ }^{23}$

\section{Study 2: Evidence from survey experiments}

To overcome the ecological inference issues of our first study and provide evidence of the motivations of Bolsonaro's supporters and opponents to respond to his cues, we conduct two experiments following the standard design used in the party cue literature (e.g., Bakker et al., 2020; Brader and Tucker, 2012; Samuels and Zucco Jr, 2014; Slothuus and Bisgaard, 2021).

\footnotetext{
${ }^{22}$ Table A.6, in the Online Appendix, also presents the effects in the sub-sample of municipalities that did not host demonstrations.

${ }^{23}$ Table A.6 in the Online Appendix also presents evidence of heterogeneous effects where we interact the support for Bolsonaro with the occurrence of demonstrations. This exercise should be read with caution since pro-government demonstrations are endogenous to support for the President. Nevertheless, the comparison between the effect of the demonstrations in pro- and anti-Bolsonaro municipalities provides evidence of the direct impact of people gathering during protests.
} 
Both of our experiments are embedded in the same online survey with a sample $(\mathrm{N}=2,992)$ that is approximately representative of the Brazilian population in terms of State of residence, gender, and age. ${ }^{24}$ The data collection was carried out by NetQuest, a market research company, in September 2021. Ahead of data collection, we received IRB approval and preregistered the hypotheses, pre-treatment questions, experimental manipulations, outcome variables, inferential rules, power analysis, data pre-processing, and regression equations. ${ }^{25}$ When discussing the analysis and results, we note any deviations from the pre-analysis plan. Furthermore, in the Online Appendix, we report results of tests that were pre-registered but could not be included in the main text due to space constraints.

\section{Experimental design and measures}

Our experiments are divided in three main parts: (1) pre-treatment questions followed by an attention check; (2) two experimental manipulations followed by the relevant outcomes separated by a filler and; (3) post-survey information on how to prevent COVID-19 infection retrieved from official sources, such as the World Health Organization (WHO). Besides collecting information on age, gender, race, State of residence, education, and religion of the respondents, we also ask batteries of questions on the following topics (specific item wording is available in the Online Appendix):

- Political social identity: we adapt Bankert et al. (2017)'s battery to our context. Specifically, we first ask whether respondents identify as Bolsonaro supporters ("Bolsonaristas") or opponents ("Anti-bolsonaristas"). If participants select "neither," we ask a follow up questions on whether they feel definitively or perhaps closer to one of these two groups. Following previous research (e.g., Bakker et al., 2020), we exclude participants who do not identify or lean towards any of these two groups.

\footnotetext{
${ }^{24}$ Descriptive statistics containing the distribution of respondents along socio-demographic variables can be found in the Online Appendix.

${ }^{25}$ See link for PAP in footnote 2.
} 
- Strength of political social identity: we include four questions adapted from Bankert et al. (2017) that measure the strength of "Bolsonarismo" and "anti-Bolsonarismo" as political social identities. As pre-registered, we create an index averaging the four items for Bolsonaro supporters $($ alpha $=0.80$, mean $=0.53$, std. $=0.23$ ) and opponents $($ alpha $=0.73$, mean $=0.57$, std. $=0.24)$.

- Cognitive resources: we use four items from the cognitive resource test battery developed by Thomson and Oppenheimer (see 2016). ${ }^{26}$ We measure cognitive resources as the percentage of correct answers $($ mean $=0.47$, std. $=0.25)$.

After responding to the pre-treatment questions and passing an attention check, ${ }^{27}$ respondents are assigned to two source cue experiments separated by a filler. ${ }^{28}$ To avoid contamination across experiments, the order of the experiments was randomized. For the same reason, we opted for assigning respondents to the same condition in both experiments (e.g., respondents assigned to the control condition in one experiment are also assigned to the control condition in the other experiment).

In the first experiment, we provide the information that scientists warn that the results of trials testing the efficiency of the nasal spray EXO-CD24 as a treatment for COVID-19 are unreliable. Respondents then read that either "some Brazilian politicians are" (control condition) or "President Bolsonaro is" (treatment condition) very optimistic about this new experimental treatment. Our outcome is an index constructed from a battery of questions on attitudes towards the nasal spray as a treatment for COVID-19 (alpha $=0.89$, mean $=$ -0.00$, std $=0.94)$

In the second experiment, we provide information that scientists recommend individuals to continue complying with COVID-19 prevention measures, such as mask wearing and social distancing. Respondents then read that a campaign to encourage compliance with such measures was approved thanks to either "some Brazilian politicians" (control condition) or

\footnotetext{
${ }^{26}$ We had to adapt one question for the Brazilian context. We discuss this in the Online Appendix.

${ }^{27}$ See the Online Appendix for information about how many participants were screened out.

${ }^{28}$ See the Online Appendix for details about the filler exercise.
} 
"President Bolsonaro" (treatment condition). ${ }^{29}$ We build our outcome measure as an index based on a battery of questions on attitudes towards COVID-19 prevention measures (alpha $=0.88$, mean $=-0.00$, std. $=0.96)$.

\section{Results}

Figure 3 and Table 2 present the treatment effect of the experiments for the sample of Bolsonaro supporters and opponents separately. We can observe in panel (a) of Figure 3 that, even in the absence of Bolsonaro's cue, his supporters are already more favorable towards the nasal spray when compared to his opponents. While Bolsonaro's cue does not change his supporters' perception about the nasal spray, it does impact his opponents' perception. More specifically, Table 2 shows that Bolsonaro's cue decreases by 0.20 standard deviations his opponents' approval for the nasal spray. In terms of magnitude, this result is higher than the effect of PT cues on anti-partisans documented by Samuels and Zucco (2018). These authors find that, on average, PT cues decrease support for a policy among PT opponents (anti-partisans) by 0.13 standard deviations.

Table 2: Effects of Bolsonaro's cues on Bolsonaro opponents and supporters

\begin{tabular}{|c|c|c|c|c|}
\hline & \multicolumn{2}{|c|}{ Support for nasal spray } & \multicolumn{2}{|c|}{ Support for social distancing } \\
\hline & $\begin{array}{c}\text { Bolsonaro } \\
\text { opponents } \\
\text { (1) }\end{array}$ & $\begin{array}{c}\text { Bolsonaro } \\
\text { supporters } \\
(2)\end{array}$ & $\begin{array}{c}\text { Bolsonaro } \\
\text { opponents } \\
(3)\end{array}$ & $\begin{array}{c}\text { Bolsonaro } \\
\text { supporters } \\
(4)\end{array}$ \\
\hline Cue nasal spray & $\begin{array}{c}-0.203^{* * *} \\
(0.041)\end{array}$ & $\begin{array}{c}0.025 \\
(0.050)\end{array}$ & & \\
\hline Cue campaign & & & $\begin{array}{c}0.000 \\
(0.026)\end{array}$ & $\begin{array}{l}0.142^{* *} \\
(0.069)\end{array}$ \\
\hline $\mathrm{N}$ & 1752 & 1240 & 1750 & 1239 \\
\hline Mean Dep. Var. & -0.325 & 0.458 & 0.306 & -0.431 \\
\hline $\mathrm{R} 2$ & 0.064 & 0.054 & 0.041 & 0.096 \\
\hline
\end{tabular}

Note: (i) Estimations include the following covariates: gender, race, religion, State of residence, age, and $\mathrm{FE}$ for the day when individuals answered the survey; (ii) * $p<0.10,{ }^{* *} p<0.05,{ }^{* * *} p<0.001$

\footnotetext{
${ }^{29}$ Details about wording of the experimental manipulation can be found in the Online Appendix.
} 

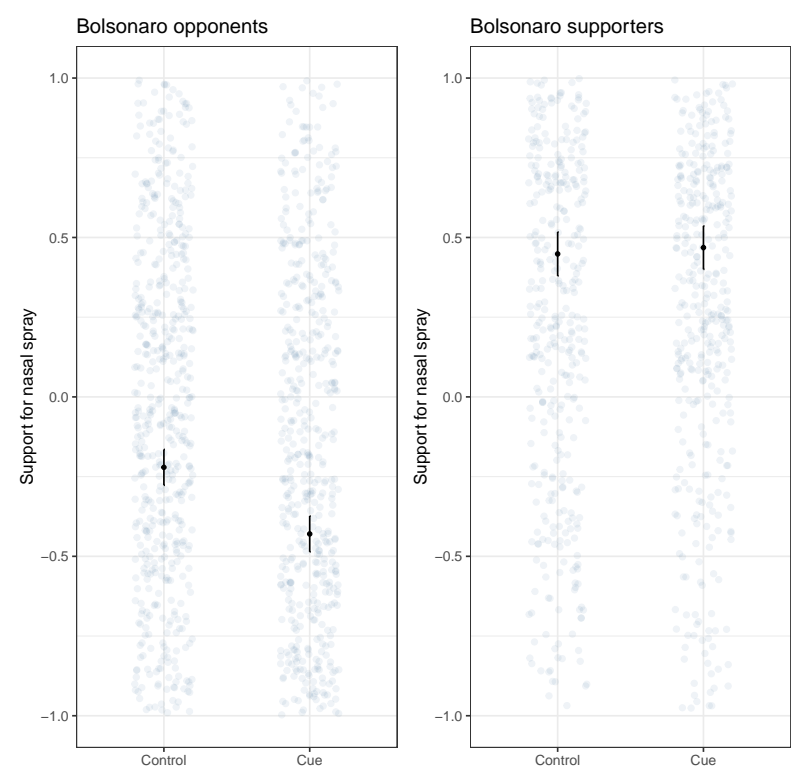

(a) Support for nasal spray
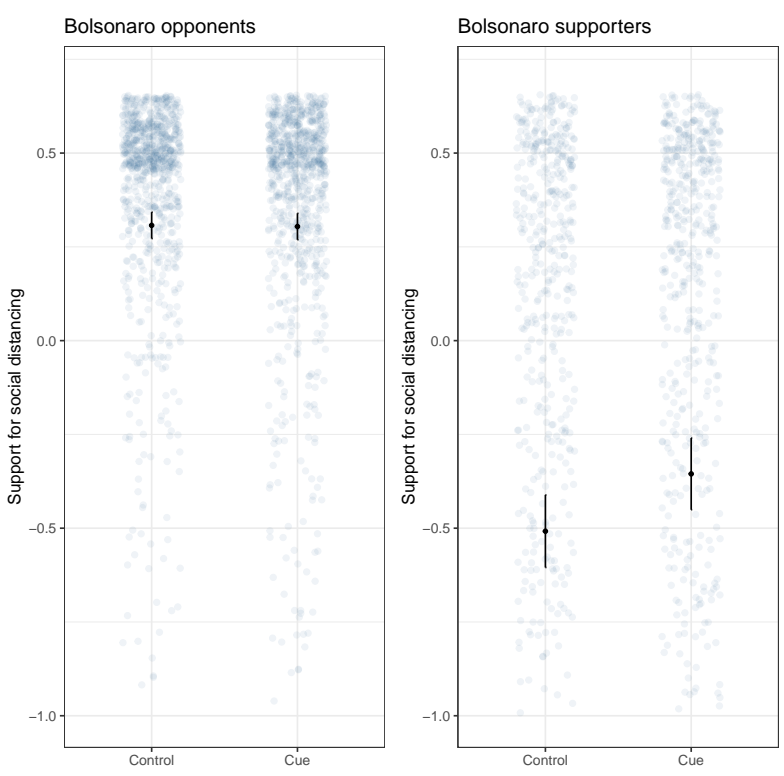

(b) Support for social distancing

Figure 3: Effects of Bolsonaro's cues on Bolsonaro opponents and supporters Notes: The figure presents the $90 \%$ of the distribution of dependent variables per treatment condition for Bolsonaro supporters and opponents as well as fitted values with $95 \%$ CIs.

When we look at participants' support for non-pharmaceutical interventions (such as mask-wearing and social distancing), we observe different patterns. We see in panel (b) of Figure 3 that Bolsonaro opponents highly approve these measures, and Bolsonaro's cue does not change their opinion. Bolsonaro supporters, in turn, tend to perceive social distancing measures much more negatively. In this case, Bolsonaro's positive cue about such measures improves related attitudes among his supporters. In particular, Table 2 shows that Bolsonaro's cue increases by 0.14 standard deviations his supporters' approval for nonpharmaceutical interventions. The magnitude of this effect is considerably smaller than the effects of PT cues on PT supporters (partisans) estimated by Samuels and Zucco (2018), which was, on average, 0.21. Overall, we find support for our hypothesis that Bolsonaro supporters react in a cue-consistent fashion, while his opponents respond in a cue-inconsistent way. This finding is in line with previous work showing that both in- and out-group cues shape voters' opinion in Brazil (Samuels and Zucco Jr, 2014; Samuels and Zucco, 2018) and elsewhere (e.g., Nicholson, 2012). However, different from their study, which focuses on party 
cues, we show that this is also the case for leader cues. We also find null effects for our sample of Bolsonaro opponents in experiment one (nasal spray) and supporters in experiment two (social distancing). A hypothesis (not pre-registered) is that such null results are explained by ceiling effects. Notably, Bolsonaro supporters are on average much more positive towards the nasal spray, while his opponents are much more in favor of non-pharmaceutical interventions.

Moving to heterogeneous treatment effects, we observe in panel (b) of figure 4 that the effect of Bolsonaro's cues in the experiment about social distancing is positive and statistically significant only among Bolsonaro supporters with high cognitive resources (i.e., above the median) and strong political social identity. In turn, as shown in panel (a), in the experiment about the nasal spray, we find negative and statistically significant results among Bolsonaro opponents with low cognitive resources (i.e., below the median) and strong political social identity, while we find positive and statistically significant results among Bolsonaro supporters with high cognitive resources and strong political social identity.

Hence, our most consistent result is that Bolsonaro supporters with high cognitive resources and strong political social identity respond to his cues in a cue-consistent way. This finding is in line with the theoretical perspective that sees cue-following as a manner to express one's political identity. However, the fact that we find statistically significant results among Bolsonaro opponents with low cognitive resources in the nasal spray experiment may indicate that heuristics drive the response of Bolsonaro opponents to his cues. An expost and not pre-registered speculation is that in-group and out-group cues prompt different psychological mechanisms. 

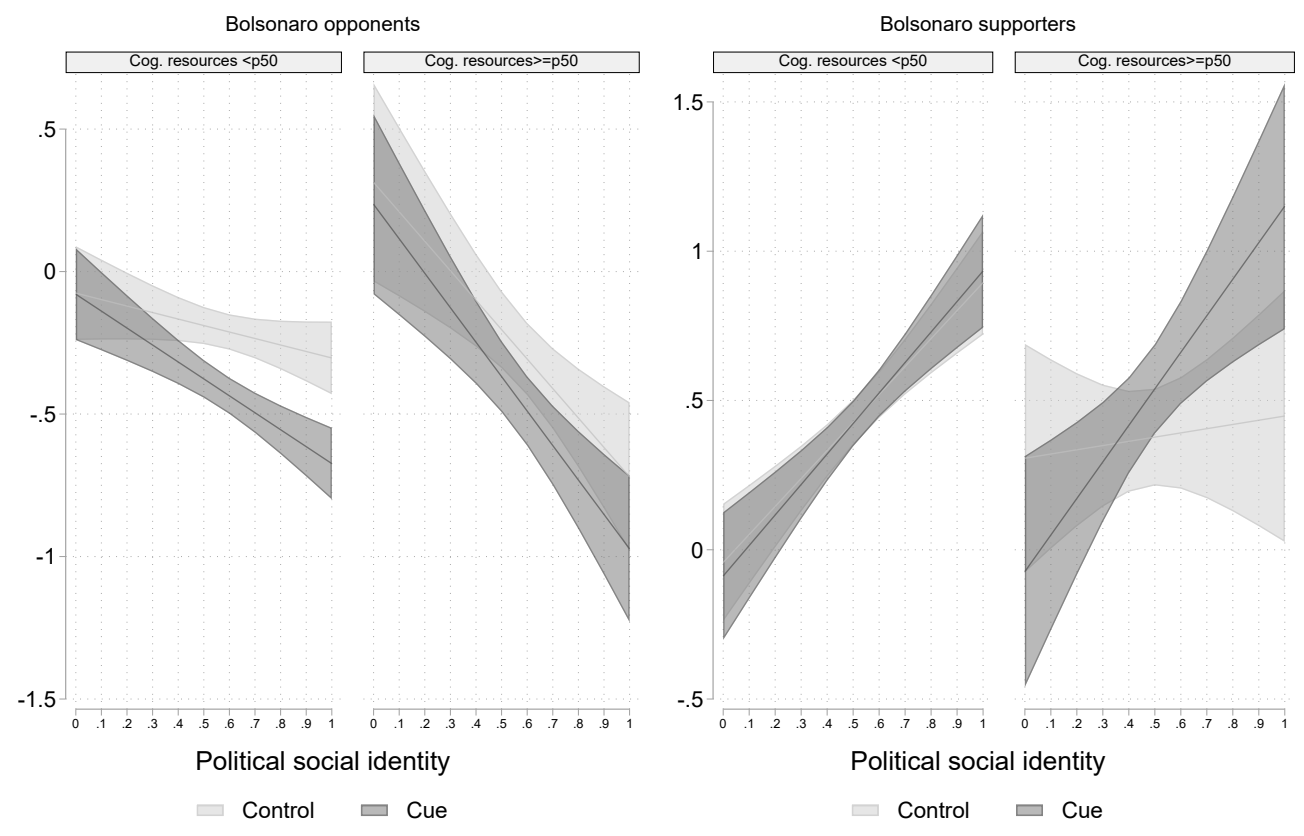

(a) Support for nasal spray
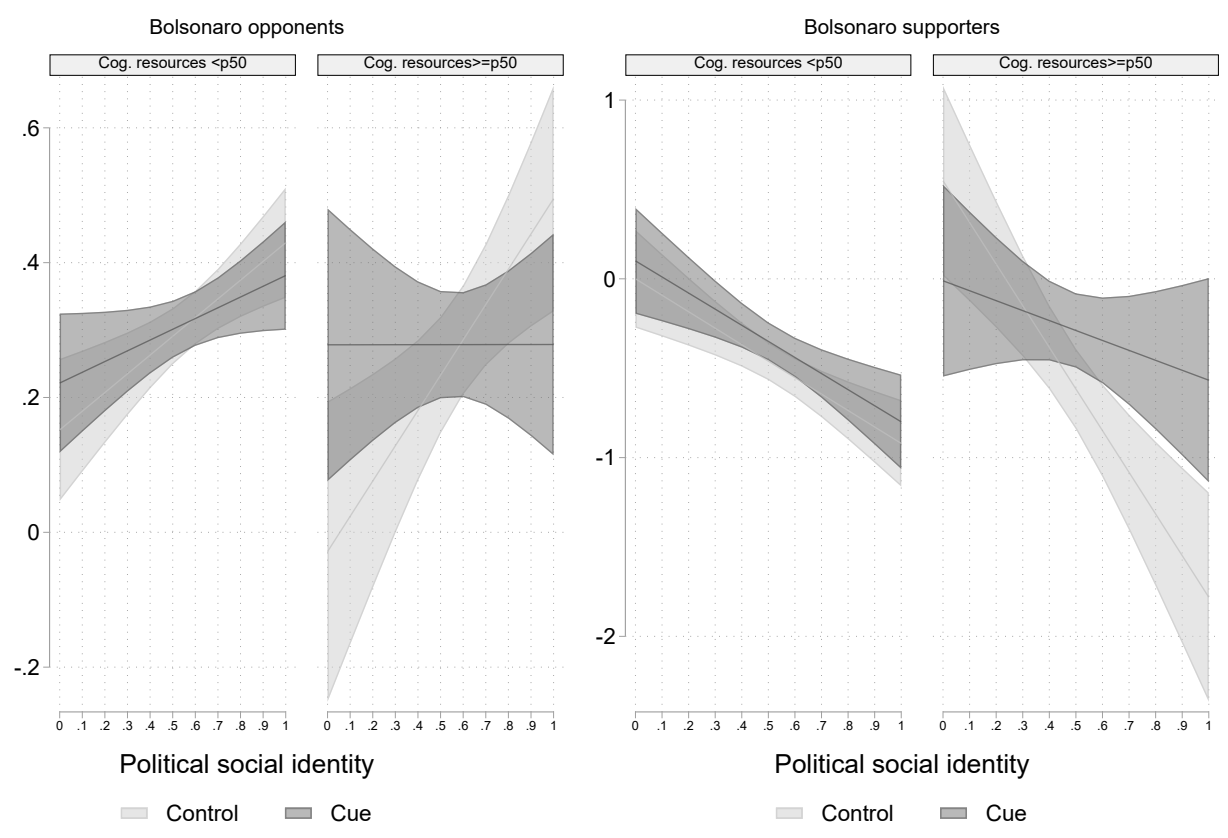

(b) Support for social distancing

Figure 4: Heterogeneity by strength of political social identity and cognitive resources Notes: (i) Graphs based on table A.8 in the Online Appendix, (ii) The figure presents the predicted values for control and treatment groups by level of cognitive resources and strength of political social identity with $95 \%$ CIs. 


\section{Discussion}

Our analyzes advance the understanding of how and why citizens react to political elites' cues when personal matters are at stake. Contrary to theoretical expectations (e.g., Groenendyk, 2013), our results indicate that in-groups may follow political elite cues to protect their political social identity even in situations where issues are salient and the decision at hand directly affects their well-being and way of life. This finding indicates that a strong attachment to political parties and figures may hinder citizens' capacity to make politicians responsive and accountable. In times of high affective polarization, the democratic dilemma might be less about whether citizens can learn what they need to know (Lupia et al., 1998) and more about whether they can put their material self-interest and values before their attachments to parties and political leaders.

More specifically, we show that President Bolsonaro's dismissive cues about COVID-19 and related policies substantially affect the attitudes and behaviors of his opponents and supporters in Brazil. In our first study, we show that in the days following Bolsonaro's first clear public display of skepticism about the risk represented by COVID-19, there was a higher prevalence of the virus in pro-Bolsonaro as opposed to anti-Bolsonaro municipalities. Specifically, the official number of COVID-19 cases surged by 16\%, while excess hospitalization, mortality, and ICU occupation increased by $22 \%, 13 \%$ and $8 \%$, respectively. We also show that this effect is driven by lower levels of social distancing in pro-Bolsonaro municipalities. Our results are consistent with previous research showing that party cues change attitudes and behaviors when citizens have a direct stake in policy (Slothuus and Bisgaard, 2021; Bisbee and Lee, 2021).

Moreover, our survey experiments suggest that these trends were caused both by Bolsonaro supporters following the President's lead and his opponents updating their beliefs in the opposite direction. This finding is consistent with previous research showing that leader cues cause both cue-following among in-groups and a backlash among out-groups (Nicholson, 2012; Samuels and Zucco Jr, 2014; Samuels and Zucco, 2018). Furthermore, we estimate 
these effects based on data collected one year and a half after the first COVID-19 case registration in Brazil. This fact indicates that political elite cues can influence decisions even when opinions are crystallized and issues are salient.

In addition, we provide evidence of the cognitive processes underlying such cue effects. Specifically, Bolsonaro supporters follow his cues as a way to express their political identity, whereas his opponents use his cues as an informational shortcut. We speculate that in and out-group cues might prompt different psychological processes. Our findings are consistent with recent research conducted in very different contexts showing that the effect of in-party cues, but not of out-party cues, tends to be driven by the desire to express one's partisan social identity (Bakker et al., 2020). Overall, our analysis provides a hard test of the expressive utility perspective for cue-taking by showing that even when we should expect directional motives to weigh little, political elite cues can lead citizens to rationalize opinion change to defend their identity.

An advantage of our analyses is combining administrative, mobility, and survey data with causal inference techniques. Most of the literature on political elite cues, including the work analyzing COVID-19 related behaviors, relies either on survey data on attitudes (e.g., Slothuus and Bisgaard, 2021; Bakker et al., 2020) or aggregate data on behavior (e.g., Bisbee and Lee, 2021). Our approach allows us to overcome the limitations of each type of data. Specifically, while the data on excess hospitalization, ICU occupation, and mortality are extremely reliable, they do not measure behavior directly. We overcome this issue by using Google mobility data which, albeit much less reliable, measures change in behavior in real time. The drawback of mobility data is that it is impossible to link it to political identity at the individual level. This is why researchers (including ourselves) aggregate mobility data and match it with electoral results. The shortcoming of inferring individual behavior from aggregate data is to incur ecological fallacies. To address this concern, we rely on two survey experiments that suggest that political elite cues influence COVID-19-related opinions not only among in-groups, but also among out-groups. Of course, survey data measure attitudes 
instead of behaviors. While no single data source or variable is perfect, we argue that by analyzing several types of data and variables, we can be more confident about our main results and provide suggestive evidence of the underlying micro-level mechanisms.

The limitations of our analysis leave open questions for future research. First, our examination of the cognitive processes underlying cue-taking relies on heterogeneous treatment effects by level of political social identity and cognitive resources, but these variables are not experimentally manipulated. Future research should address this concern by directly manipulating these variables (this point was also made by Bakker et al., 2020). Second, previous research applies different measures of cognitive resources. Some examples are factual knowledge about politics, the need for cognition, and performance on cognitive resource tests. However, it is unclear whether these variables measure the same concept (Bullock, 2020). Future work should investigate this question. ${ }^{30}$ Finally, the research on political elite cues has overwhelmingly focused on party cues. Yet, our and previous research show that political leader cues also influence opinions and behaviors (Bisbee and Lee, 2021; Nicholson, 2012). In future work, it is important to theorize and test how party and leader cues differ from each other. In this study, we have shown that Brazilians reacted to the cues of President Bolsonaro during the COVID-19 pandemic and that these cue effects had important implications to their health-related behavior. This evidence illustrates the important real-life consequences of political elite communication.

\section{References}

Ajzenman, N., T. Cavalcanti, and D. Da Mata (2021). More than words: Leaders' speech and risky behavior during a pandemic. Unpublished manuscript.

\footnotetext{
${ }^{30} \mathrm{We}$, however, highlight that, contrary to the concerns raised by Bakker et al. (2020), our heterogeneous treatment effects by performance on the cognitive resource test do not seem to be driven by a correlation between performance in this test and the capacity to read and understand the text used in the experimental manipulation for two main reasons. First, we find that the Bolsonaro opponents who perform more poorly on this test react more strongly to his cues. Second, our demanding attention check was designed to select only individuals that carefully read and understand somewhat long texts.
} 
Amaral, O. E. d. (2020). The victory of jair bolsonaro according to the brazilian electoral study of 2018. Brazilian Political Science Review 14.

Ames, B. (2001). The deadlock of democracy in Brazil. Interests, identities, and institutions in comparative politics. Ann Arbor: University of Michigan Press.

Apsler, R. and D. O. Sears (1968). Warning, personal involvement, and attitude change. Journal of personality and social psychology 9, 162.

Arceneaux, K. and R. J. Vander Wielen (2017). Taming intuition: How reflection minimizes partisan reasoning and promotes democratic accountability. Cambridge University Press.

Bakker, B. N., Y. Lelkes, and A. Malka (2020). Understanding partisan cue receptivity: Tests of predictions from the bounded rationality and expressive utility perspectives. The Journal of Politics 82(3), 1061-1077.

Bankert, A., L. Huddy, and M. Rosema (2017). Measuring partisanship as a social identity in multi-party systems. Political behavior 39(1), 103-132.

Basellini, U., D. Alburez-Gutierrez, E. Del Fava, D. Perrotta, M. Bonetti, C. G. Camarda, and E. Zagheni (2020). Linking excess mortality to google mobility data during the covid19 pandemic in england and wales. Unpublished manuscript.

Bellemare, M. F. and C. J. Wichman (2020). Elasticities and the inverse hyperbolic sine transformation. Oxford Bulletin of Economics and Statistics 82(1), 50-61.

Bisbee, J. and D. D. I. Lee (2021). Objective Facts and Elite Cues: Partisan Responses to Covid-19. The Journal of Politics.

Boninger, D. S., J. A. Krosnick, and M. K. Berent (1995). Origins of attitude importance: Self-interest, social identification, and value relevance. Journal of personality and social psychology 68(1), 61 . 
Brader, T. and J. A. Tucker (2012). Following the party's lead: Party cues, policy opinion, and the power of partisanship in three multiparty systems. Comparative Politics 44(4), 403-403.

Bullock, J. G. (2011). Elite influence on public opinion in an informed electorate. American Political Science Review 105(3), 496-515.

Bullock, J. G. (2020). Party cues. In The Oxford handbook of electoral persuasion, pp. 129. Oxford University Press, USA.

Campbell, A., P. E. Converse, W. E. Miller, and D. E. Stokes (1980). The american voter. University of Chicago Press.

Carsey, T. M. and G. C. Layman (2006). Changing sides or changing minds? party identification and policy preferences in the american electorate. American Journal of Political Science 50(2), 464-477.

Chen, F. and F. Toxvaerd (2014). The economics of vaccination. Journal of theoretical biology 363, 105-117.

Cota, W. (2021). Monitoramento do número de casos de covid-19 no brasil. accessed January $20,2022$.

de Souza, W. M., L. F. Buss, D. da Silva Candido, J.-P. Carrera, S. Li, A. E. Zarebski, R. H. M. Pereira, C. A. Prete, A. A. de Souza-Santos, K. V. Parag, et al. (2020). Epidemiological and clinical characteristics of the covid-19 epidemic in brazil. Nature Human Behaviour, 1-9.

Druckman, J. N., E. Peterson, and R. Slothuus (2013). How Elite Partisan Polarization Affects Public Opinion Formation. American Political Science Review 107(1), 57-79.

Folha de São Paulo (2021, Mar). Relembre o que bolsonaro já disse sobre a pandemia, de gripezinha e país de maricas a frescura e mimimi. accessed January 20, 2022. 
Foos, F. and D. Bischof (2021). Tabloid media campaigns and public opinion: Quasiexperimental evidence on euroscepticism in england. American Political Science Review.

Frantz, E., A. Kendall-Taylor, C. Nietsche, and J. Wright (2021). How personalist politics is changing democracies. Journal of Democracy 32(3), 94-108.

Fujiwara, T. et al. (2011). A regression discontinuity test of strategic voting and duverger's law. Quarterly Journal of Political Science 6(3-4), 197-233.

Gadarian K., S., S. W. Goodman, and T. P. Pepinsky (2022). Pandemic Politics: How COVID-19 Exposed the Depth of American Polarization. Princeton University Press.

Gazeta do Povo (2020). Quem está organizando e onde devem ocorrer as manifestaćões pró-bolsonaro. accessed January 19, 2022.

Google (2022). Overview - community mobility reports help. accessed January 19, 2022.

Groenendyk, E. (2013). Competing motives in the partisan mind: How loyalty and responsiveness shape party identification and democracy. Oxford University Press.

Hallal, P. C., F. P. Hartwig, B. L. Horta, M. F. Silveira, C. J. Struchiner, L. P. Vidaletti, N. A. Neumann, L. C. Pellanda, O. A. Dellagostin, M. N. Burattini, G. D. Victora, A. M. B. Menezes, F. C. Barros, A. J. D. Barros, and C. G. Victora (2020). Sars-cov-2 antibody prevalence in brazil: results from two successive nationwide serological household surveys. The Lancet Global Health 8(11).

Heutel, G., N. H. Miller, and D. Molitor (2020). Adaptation and the mortality effects of temperature across u.s. climate regions. The Review of Economics and Statistics 0(ja), $1-33$.

Huang, C., Y. Wang, X. Li, L. Ren, J. Zhao, Y. Hu, L. Zhang, G. Fan, J. Xu, X. Gu, and et al. (2020). Clinical features of patients infected with 2019 novel coronavirus in wuhan, china. The Lancet (British edition) 395(10223), 497-506. 
Justen, (2022). Covid-19 - datasets. accessed January 20, 2022.

Kam, C. D. (2005). Who Toes the Party Line? Cues, Values, and Individual Differences. Political Behavior 27(2), 163-182.

Linton, N. M., T. Kobayashi, Y. Yang, K. Hayashi, A. R. Akhmetzhanov, S.-m. Jung, B. Yuan, R. Kinoshita, and H. Nishiura (2020). Incubation period and other epidemiological characteristics of 2019 novel coronavirus infections with right truncation: A statistical analysis of publicly available case data. Journal of Clinical Medicine 9(2).

Lipset, S. M. and S. Rokkan (1967). Party systems and voter alignments: Cross-national perspectives, Volume 7. Free press.

Lodge, M. and C. S. Taber (2013). The rationalizing voter. Cambridge University Press.

Lupia, A. (1994). Shortcuts versus encyclopedias: Information and voting behavior in california insurance reform elections. American Political Science Review 88(1), 63-76.

Lupia, A., M. D. McCubbins, L. Arthur, et al. (1998). The democratic dilemma: Can citizens learn what they need to know? Cambridge University Press.

Mainwaring, S. and T. Scully (1995). Building democratic institutions: Party systems in Latin America. Stanford Univ Pr.

Marshall, E. (2020). Brazil president jair bolsonaro ignores coronavirus warnings to take selfies with demonstrators. accessed January 20, 2022.

Martin, G. J. and A. Yurukoglu (2017). Bias in cable news: Persuasion and polarization. American Economic Review 107(9), 2565-99.

Mullinix, K. J. (2016). Partisanship and Preference Formation: Competing Motivations, Elite Polarization, and Issue Importance. Political Behavior 38(2), 383-411. 
Nicholson, S. P. (2011). Dominating Cues and the Limits of Elite Influence. The Journal of Politics $73(4), 1165-1177$.

Nicholson, S. P. (2012). Polarizing cues. American journal of political science 56(1), 52-66.

Nisbett, R. E. and L. Ross (1980). Human inference: Strategies and shortcomings of social judgment. Upper Saddle River, NJ: Prentice Hall.

Petersen, M. B., M. Skov, S. Serritzlew, and T. Ramsoy (2013). Motivated Reasoning and Political Parties: Evidence for Increased Processing in the Face of Party Cues. Political Behavior 35(4).

Prior, M., G. Sood, and K. Khanna (2015). You Cannot be Serious: The Impact of Accuracy Incentives on Partisan Bias in Reports of Economic Perceptions. Quarterly Journal of Political Science 10(4).

Rosa, A., A. Farias, G. Valentim, and L. Herzog (2020). Direitos na pandemia: mapeamento e análise das normas jurídicas de resposta à covid-19. São Paulo: Conectas.

Samuels, D. (2003). Ambition, Federalism, and Legislative Politics in Brazil. Cambridge: Cambridge University Press.

Samuels, D. and C. Zucco Jr (2014). The power of partisanship in brazil: Evidence from survey experiments. American Journal of Political Science 58(1), 212-225.

Samuels, D. J. and C. Zucco (2018). Partisans, Antipartisans, and Nonpartisans: Voting Behavior in Brazil (1 ed.). Cambridge University Press.

Slothuus, R. and M. Bisgaard (2021). Party over Pocketbook? How Party Cues Influence Opinion When Citizens Have a Stake in Policy. American Political Science Review 115(3), 1090-1096.

Thomson, K. S. and D. M. Oppenheimer (2016). Investigating an alternate form of the cognitive reflection test. Judgment and Decision Making 11(1), 15. 
Toulemon, L. and M. Barbieri (2008). The mortality impact of the august 2003 heat wave in france: Investigating the "harvesting" effect and other long-term consequences. Population Studies 62(1), 39-53.

Verity, R., L. C. Okell, I. Dorigatti, P. Winskill, C. Whittaker, N. Imai, G. CuomoDannenburg, H. Thompson, P. G. T. Walker, H. Fu, and et al. (2020). Estimates of the severity of coronavirus disease 2019: a model-based analysis. The Lancet infectious diseases 20(6), 669-677.

Zhou, X., K. Josey, L. Kamareddine, M. C. Caine, T. Liu, L. J. Mickley, M. Cooper, and F. Dominici (2021). Excess of covid-19 cases and deaths due to fine particulate matter exposure during the 2020 wildfires in the united states. Science advances $7(33)$.

Zucco, C., T. J. Power, et al. (2021). Fragmentation without cleavages? endogenous fractionalization in the brazilian party system. Comparative Politics 53(3), 477-500. 


\section{A Online appendix}

\section{Descriptive statistics - study 1}

Table A.1: Descriptive Statistics for pro- and anti-Bolsonaro municipalities

\begin{tabular}{lcccc}
\hline \hline & $(1)$ & $(2)$ & $(3)$ & $(4)$ \\
& All & Pro-Bolsonaro & Anti-Bolsonaro & Diff. $((3)-(2))$ \\
\hline Pro-Bolsonaro & 0.53 & 1.00 & 0.00 & \\
Demonstrations & 0.05 & 0.08 & 0.01 & $-0.07^{* * *}$ \\
Confirmed COVID-19 cases (March 1) & 0.00 & 0.00 & 0.00 & -0.00 \\
Excess hospitalization (March 1) & 0.41 & 0.53 & 0.26 & $-0.27^{* *}$ \\
Excess ICU use (March 1) & 0.16 & 0.22 & 0.09 & $-0.13^{* *}$ \\
Excess death (March 1) & 0.02 & 0.04 & 0.01 & $-0.03^{* * *}$ \\
Population (2018) & $41,124.37$ & $55,806.42$ & $24,749.45$ & $-31,056.98^{* * *}$ \\
Pop. density (pop./km $\left.{ }^{2}\right)(2018)$ & 133.67 & 202.62 & 56.79 & $-145.82^{* * *}$ \\
Share of people over 60 y.o. (2010) & 0.12 & 0.13 & 0.11 & $-0.01^{* * *}$ \\
Share of illiterate (2010) & 0.16 & 0.09 & 0.24 & $0.15^{* * *}$ \\
Share of women (2010) & 0.50 & 0.50 & 0.50 & -0.00 \\
GDP/capita (2015) & 19.97 & 27.56 & 11.49 & $-16.07^{* * *}$ \\
\hline $\mathrm{N}$ & 4,887 & 2,571 & 2,307 & \\
\hline \hline
\end{tabular}



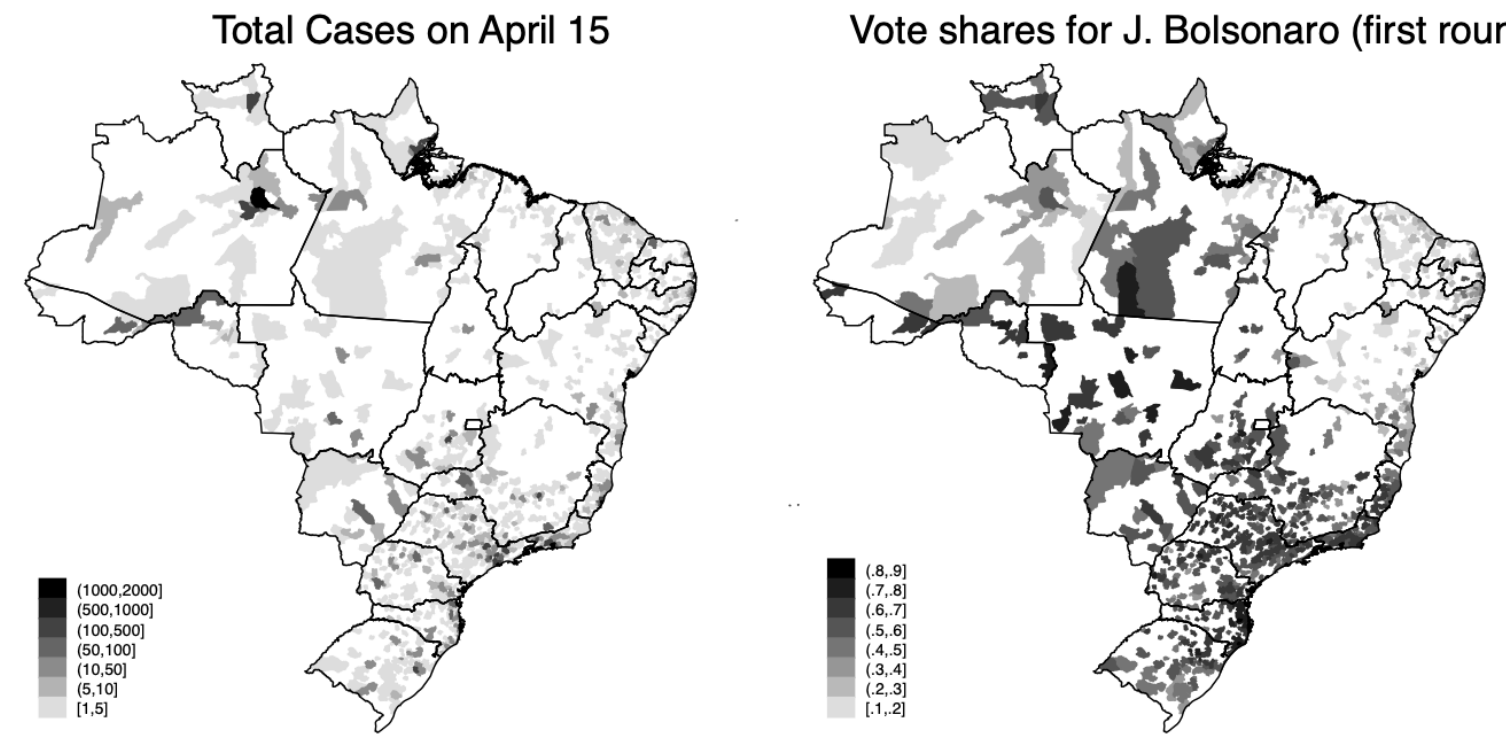

Figure A.1: Geographical distribution of COVID-19 cases and vote shares for Bolsonaro at the first round of the 2018 Presidential Election 


\section{Complementary results - study 1}

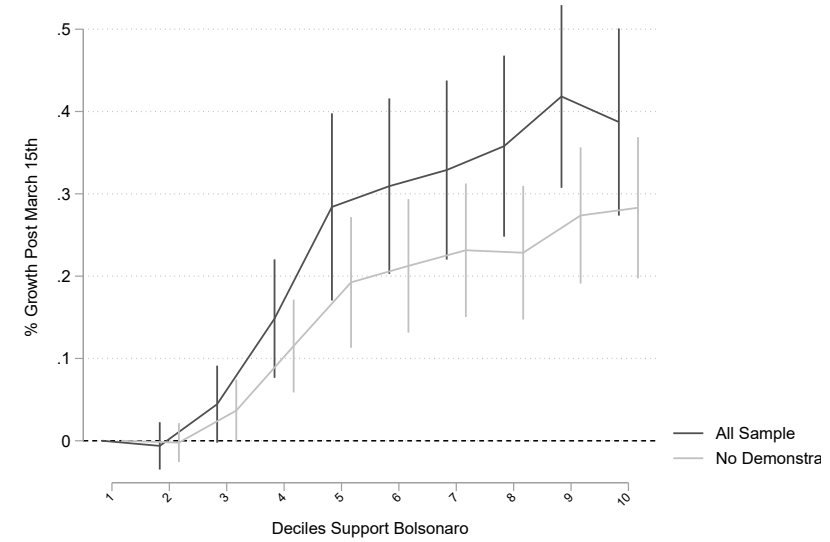

(a) Number of confirmed cases

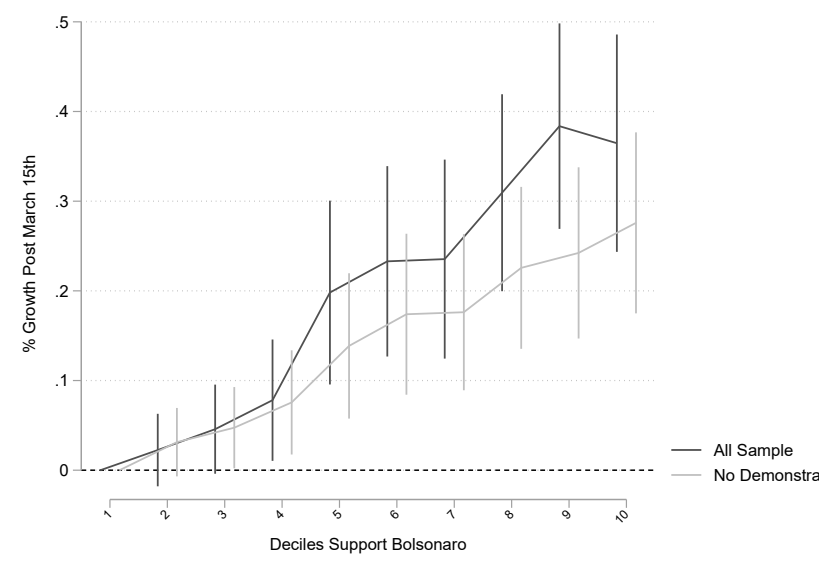

(c) Excess ICU

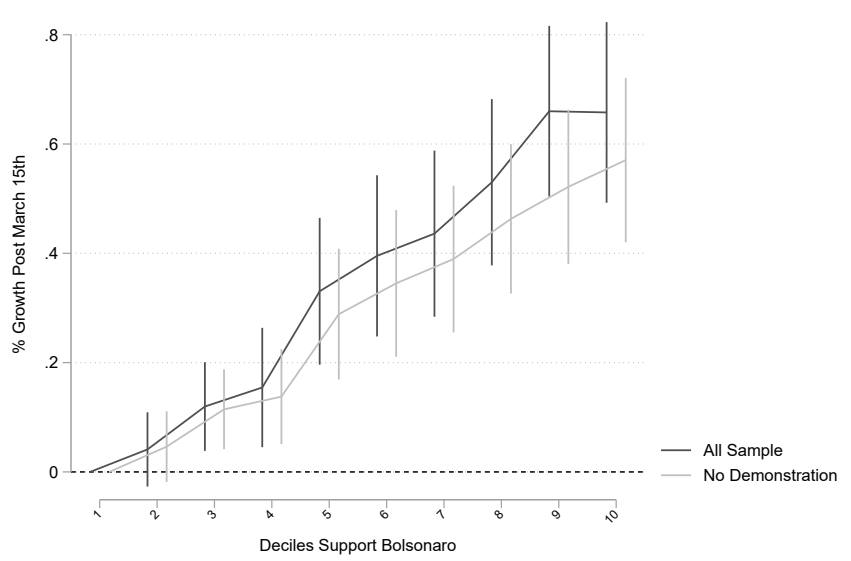

(b) Excess of Hospitalization

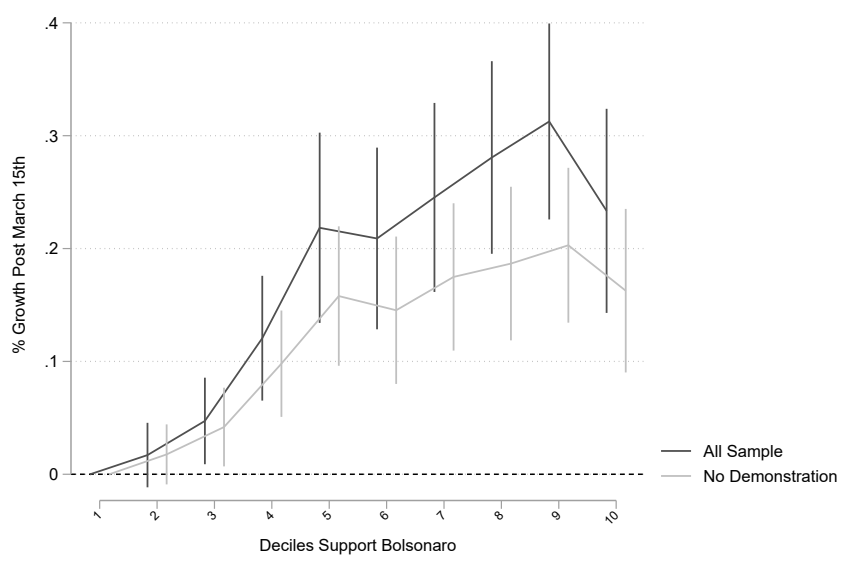

(d) Excess of Deaths

Figure A.2: Disproportional COVID-19 spread by deciles of Bolsonaro vote shares

Notes: (i) Each of these graphs show coefficients of estimations of equation 1 for each decile of vote shares for Bolsonaro in the first round of the 2018 Presidential election (ii) Reported 95\% confidence intervals are based on standard-errors clustered at municipality level and commuting zone

$\mathrm{x}$ Time FE level; (iii) Regression controls for time interactions with population density, number of cases before the demonstrations, and fixed-effects for commuting zone-date and municipality.

\section{Placebo test - 2019 flu vaccination campaign}

We explore flu immunization data that contain information on how many flu shots were taken each month in each municipality during the 2019 vaccination campaign. This exercise shows that pro- and anti- municipalities do not present different flu vaccine take-up levels, which supports our claims that the President's cues are driving our results as opposed to pre-existing beliefs about public health measures and authorities. To perform this test, we 
gather data from the information system of the national immunization program (Sistema de Informaçoes do Programa Nacional de Imunizaçoes).

Similarly to social isolation amid the COVID-19 epidemic, low compliance levels with flu vaccination can increase hospitalization, ICU admissions, and deaths due to flu-like illness.

Country-wide flu vaccination campaigns have been carried out every year in Brazil since 1999, and it has been a relatively successful strategy to reduce serious flu-like illness (Sato et al., 2015). The take-up has increased over the years, reaching $97.1 \%$ of the targeted population in 2018 (Ministério da Saúde, 2019). 2019 is the first year of President Bolsonaro's mandate. We analyze take-up in this year to understand if support for the President is correlated with other characteristics that can predict compliance with health measures. Notably, President Bolsonaro did not voice any opposition to or support for this campaign.

Figure A.3 displays exercises comparing pro- and anti-Bolsonaro municipalities around the flu vaccination campaign that began in April of 2019. We look at differences in terms of flu immunization and excess hospitalization, admission to ICU, and mortality due to flulike illness for each month of 2019. ${ }^{1}$ The measure of immunization is the hyperbolic sine transformation of the number of flu shots delivered in each municipality. The measures of excess hospitalization, ICU use, and deaths are built in the same way as described before, but for 2019 instead of 2020. The dashed line in the graphs marks the beginning of the vaccination campaign in April.

\footnotetext{
${ }^{1}$ According to Alonso et al. (2007), the flu season in Brazil spans from March/April in the North and until the end of July in the South. The authors also show that the flu peaks in June and July.
} 


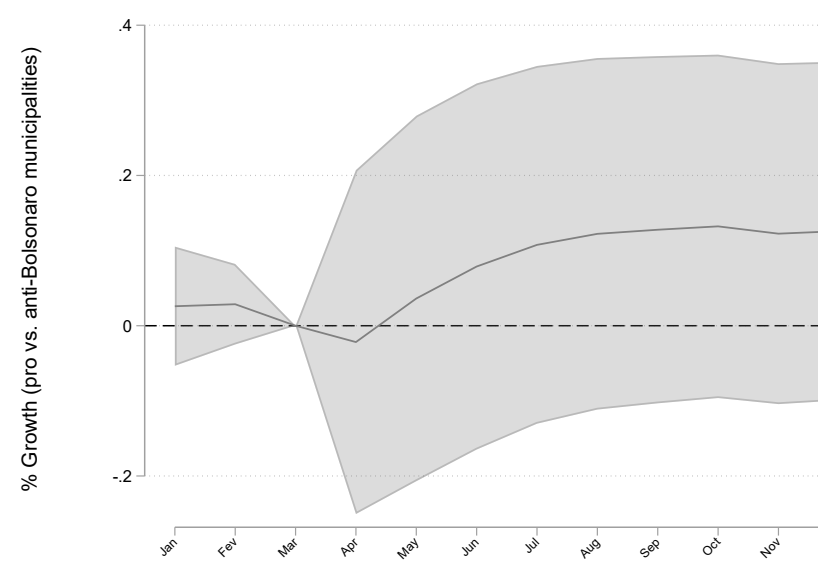

Immunization

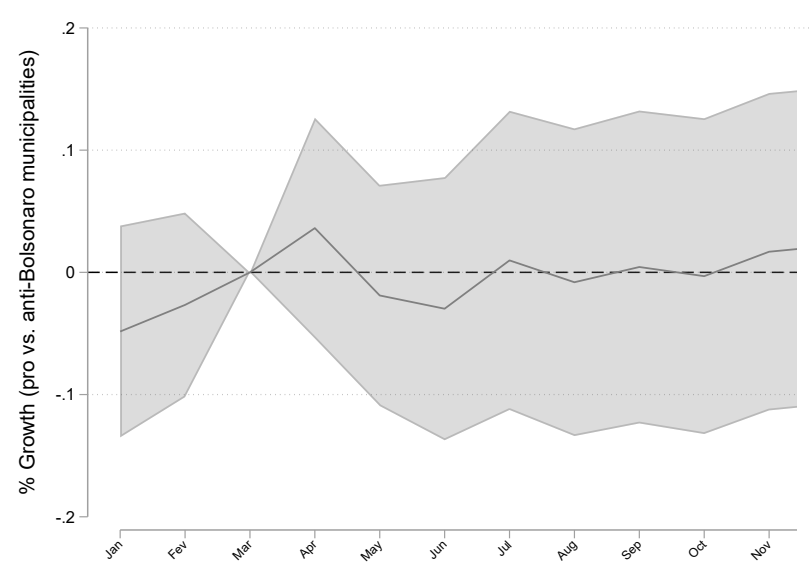

Admission into ICU

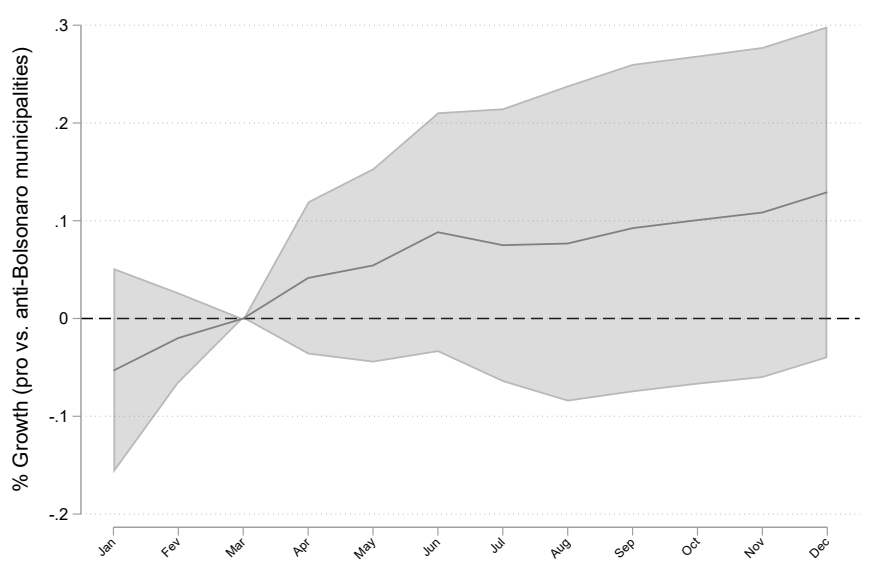

Hospitalization

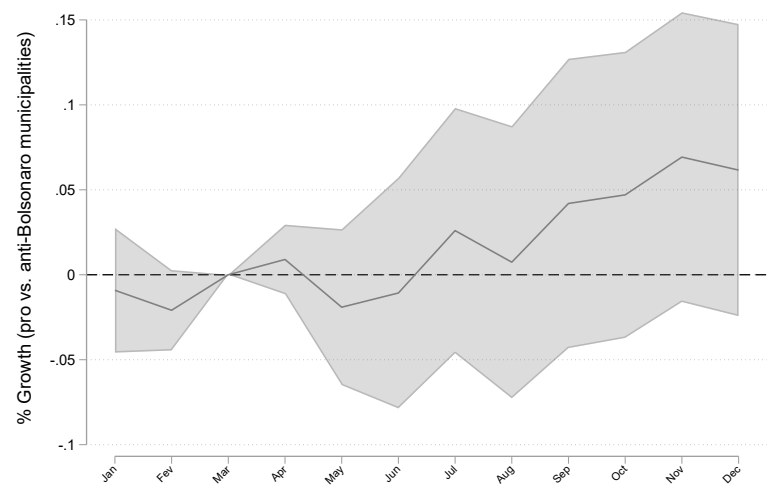

Deaths

Figure A.3: Placebo tests using flu immunization and excess of hospitalizations, ICU use, and deaths in Pro-Bolsonaro municipalities - compared to anti-Bolsonaro municipalities after the flu vaccination campaign in 2019

Notes: (i) Reported 95\% confidence intervals are based on standard-errors clustered at municipality level and commuting zone x Time FE level; (ii) Dashed line indicates the beginning of vaccinations campaign on April 10 2019. (iii) Regression controls for time interactions with population density, and fixed-effects for commuting zone-date and municipality.

The results show that Pro-Bolsonaro municipalities did not display lower levels of immunization, or higher levels of flu-like illness in 2019, as compared to municipalities where support for the President is lower. This provides further evidence that our results are driven by the President's cues and not by voters' pre-existing characteristics. 


\section{Robustness checks - study 1}

Table A.2: Controlling for local demonstrations on March 15 and restricting sample to municipalities without demonstrations

\begin{tabular}{|c|c|c|c|c|c|c|c|c|}
\hline & \multicolumn{2}{|c|}{$\begin{array}{c}\text { Confirmed } \\
\text { cases }\end{array}$} & \multicolumn{2}{|c|}{$\begin{array}{c}\text { Excess } \\
\text { hospitalization }\end{array}$} & \multicolumn{2}{|c|}{$\begin{array}{c}\text { Excess } \\
\text { ICU }\end{array}$} & \multicolumn{2}{|c|}{$\begin{array}{l}\text { Excess } \\
\text { death }\end{array}$} \\
\hline & $(1)$ & $(2)$ & $(3)$ & $(4)$ & $(5)$ & $(6)$ & $(7)$ & $(8)$ \\
\hline Post March $15 \times$ Pro-Bolsonaro & $\begin{array}{c}0.123^{* * *} \\
(0.022)\end{array}$ & $\begin{array}{c}0.092^{* * *} \\
(0.018)\end{array}$ & $\begin{array}{c}0.196^{* * *} \\
(0.041)\end{array}$ & $\begin{array}{r}0.181^{* * *} \\
(0.038)\end{array}$ & $\begin{array}{c}0.110^{* * *} \\
(0.028)\end{array}$ & $\begin{array}{c}0.084^{* * *} \\
(0.024)\end{array}$ & $\begin{array}{r}0.059^{* * *} \\
(0.018)\end{array}$ & $\begin{array}{c}0.046^{* * *} \\
(0.016)\end{array}$ \\
\hline Observations & 224,342 & 213,486 & 224,342 & 213,486 & 224,342 & 213,486 & 224,342 & 213,486 \\
\hline R Squared & 0.72 & 0.61 & 0.84 & 0.81 & 0.82 & 0.80 & 0.75 & 0.71 \\
\hline Municipality FE & $\checkmark$ & $\checkmark$ & $\checkmark$ & $\checkmark$ & $\checkmark$ & $\checkmark$ & $\checkmark$ & $\checkmark$ \\
\hline Commuting zone $\mathrm{x}$ Time FE & $\checkmark$ & $\checkmark$ & $\checkmark$ & $\checkmark$ & $\checkmark$ & $\checkmark$ & $\checkmark$ & $\checkmark$ \\
\hline Pre-demo number of cases $\mathrm{x}$ Time FE & $\checkmark$ & $\checkmark$ & $\checkmark$ & $\checkmark$ & $\checkmark$ & $\checkmark$ & $\checkmark$ & $\checkmark$ \\
\hline Population Density x Time FE & $\checkmark$ & $\checkmark$ & $\checkmark$ & $\checkmark$ & $\checkmark$ & $\checkmark$ & $\checkmark$ & $\checkmark$ \\
\hline Demonstration $\mathrm{x}$ Time FE & $\checkmark$ & & $\checkmark$ & & $\checkmark$ & & $\checkmark$ & \\
\hline Municipalities with Demonstration & $\checkmark$ & & $\checkmark$ & & $\checkmark$ & & $\checkmark$ & \\
\hline
\end{tabular}

Table A.3: Descriptive statistics on dependent variables - municipalities with at least one confirmed case before April 15

\begin{tabular}{lcccc}
\hline \hline & $(1)$ & $(2)$ & $(3)$ & $(4)$ \\
& All & Pro-Bolsonaro & Anti-Bolsonaro & Diff. $((3)-(2))$ \\
\hline Confirmed COVID-19 cases (March 1) & 0.00 & 0.00 & 0.00 & -0.00 \\
Excess hospitalization (March 1) & 1.51 & 1.56 & 1.39 & -0.16 \\
Excess ICU use (March 1) & 0.59 & 0.63 & 0.48 & -0.15 \\
Excess death (March 1) & 0.08 & 0.10 & 0.04 & -0.06 \\
\hline \hline $\mathrm{N}$ & 1,150 & 789 & 361 & \\
\hline \hline
\end{tabular}


Table A.4: Restricting sample to municipalities with at least one confirmed case before April 15

\begin{tabular}{lcccc}
\hline \hline & $\begin{array}{c}(1) \\
\text { Confirmed } \\
\text { cases }\end{array}$ & $\begin{array}{c}(2) \\
\text { Excess } \\
\text { hospitalization }\end{array}$ & $\begin{array}{c}\text { Excess } \\
\text { ICU }\end{array}$ & $\begin{array}{c}(4) \\
\text { Excess } \\
\text { death }\end{array}$ \\
\hline Post March $15 \times$ Pro-Bolsonaro & $0.551^{* * *}$ & $0.467^{* * *}$ & $0.370^{* * *}$ & $0.242^{* * *}$ \\
& $(0.113)$ & $(0.132)$ & $(0.113)$ & $(0.090)$ \\
\hline Observations & 52,486 & 52,486 & 52,486 & 52,486 \\
R Squared & 0.79 & 0.90 & 0.88 & 0.80 \\
Municipality FE & $\checkmark$ & $\checkmark$ & $\checkmark$ & $\checkmark$ \\
Commuting zone x Time FE & $\checkmark$ & $\checkmark$ & $\checkmark$ & $\checkmark$ \\
Pre-demo number of cases x Time FE & $\checkmark$ & $\checkmark$ & $\checkmark$ & $\checkmark$ \\
Population Density x Time FE & $\checkmark$ & $\checkmark$ & $\checkmark$ & $\checkmark$ \\
\hline \hline
\end{tabular}


Table A.5: Controlling for non-linear trends in variables related to Covid-19

\begin{tabular}{|c|c|c|c|c|c|}
\hline \multirow[b]{3}{*}{ Post March $15 \times$ Pro-Bolsonaro } & (1) & $(2)$ & $(3)$ & $(4)$ & $(5)$ \\
\hline & \multicolumn{5}{|c|}{ Number of confirmed cases } \\
\hline & $\begin{array}{c}0.117^{* * *} \\
(0.024)\end{array}$ & $\begin{array}{c}0.162^{* * *} \\
(0.025)\end{array}$ & $\begin{array}{c}0.126^{* * *} \\
(0.024)\end{array}$ & $\begin{array}{c}0.061^{* * *} \\
(0.023)\end{array}$ & $\begin{array}{r}0.107^{* * *} \\
(0.024)\end{array}$ \\
\hline \multirow[b]{2}{*}{ Post March $15 \times$ Pro-Bolsonaro } & \multicolumn{5}{|c|}{ Excess hospitalization } \\
\hline & $\begin{array}{c}0.097^{* * *} \\
(0.032)\end{array}$ & $\begin{array}{c}0.222^{* * *} \\
(0.035) \\
\end{array}$ & $\begin{array}{c}0.157^{* * *} \\
(0.034) \\
\end{array}$ & $\begin{array}{c}0.092^{* * *} \\
(0.033) \\
\end{array}$ & $\begin{array}{c}0.143^{* * *} \\
(0.034) \\
\end{array}$ \\
\hline \multirow[b]{2}{*}{ Post March $15 \times$ Pro-Bolsonaro } & \multicolumn{5}{|c|}{ Excess ICU } \\
\hline & $\begin{array}{c}0.069^{* * *} \\
(0.024) \\
\end{array}$ & $\begin{array}{c}0.132^{* * *} \\
(0.025) \\
\end{array}$ & $\begin{array}{c}0.094^{* * *} \\
(0.025) \\
\end{array}$ & $\begin{array}{l}0.048^{* *} \\
(0.023) \\
\end{array}$ & $\begin{array}{c}0.082^{* * *} \\
(0.024)\end{array}$ \\
\hline \multirow[b]{2}{*}{ Post March $15 \times$ Pro-Bolsonaro } & \multicolumn{5}{|c|}{ Excess death } \\
\hline & $\begin{array}{l}0.039^{* *} \\
(0.018)\end{array}$ & $\begin{array}{c}0.083^{* * *} \\
(0.019)\end{array}$ & $\begin{array}{c}0.055^{* * *} \\
(0.019)\end{array}$ & $\begin{array}{c}0.026 \\
(0.018)\end{array}$ & $\begin{array}{c}0.046^{* *} \\
(0.019)\end{array}$ \\
\hline Observations & 224,342 & 224,342 & 224,342 & 224,342 & 224,342 \\
\hline Municipality FE & $\checkmark$ & $\checkmark$ & $\checkmark$ & $\checkmark$ & $\checkmark$ \\
\hline Commuting zone $\mathrm{x}$ Time FE & $\checkmark$ & $\checkmark$ & $\checkmark$ & $\checkmark$ & $\checkmark$ \\
\hline Pre-demo number of cases $\mathrm{x}$ Time FE & $\checkmark$ & $\checkmark$ & $\checkmark$ & $\checkmark$ & $\checkmark$ \\
\hline Population Density x Time FE & $\checkmark$ & $\checkmark$ & $\checkmark$ & $\checkmark$ & $\checkmark$ \\
\hline Population x Time FE & $\checkmark$ & & & & \\
\hline Share of people over 60 y.o. X Time FE & & $\checkmark$ & & & \\
\hline Share of women $\mathrm{x}$ Time FE & & & $\checkmark$ & & \\
\hline Adult literacy rate $\mathrm{x}$ Time FE & & & & $\checkmark$ & \\
\hline GDP/capita $x$ Time FE & & & & & $\checkmark$ \\
\hline
\end{tabular}


Table A.6: Heterogeneous impacts on municipalities with and without local demonstrations on March 15

\begin{tabular}{|c|c|c|c|c|}
\hline & $\begin{array}{c}(1) \\
\text { Confirmed cases }\end{array}$ & $\begin{array}{c}(2) \\
\text { Excess hosp. }\end{array}$ & $\begin{array}{c}(3) \\
\text { Excess ICU }\end{array}$ & $\begin{array}{c}(4) \\
\text { Excess death }\end{array}$ \\
\hline Post March $15 \times$ Local demonstration $=0 \times$ Pro-Bolsonaro $=1$ & $\begin{array}{c}0.126^{* * *} \\
(0.022)\end{array}$ & $\begin{array}{l}0.191^{* * *} \\
(0.041)\end{array}$ & $\begin{array}{l}0.103^{* * *} \\
(0.028)\end{array}$ & $\begin{array}{c}0.058^{* * *} \\
(0.018)\end{array}$ \\
\hline Post March $15 \times$ Local demonstration $=1 \times$ Pro-Bolsonaro $=0$ & $\begin{array}{c}0.899^{* * *} \\
(0.282)\end{array}$ & $\begin{array}{c}0.786^{* * *} \\
(0.276)\end{array}$ & $\begin{array}{l}0.415^{* *} \\
(0.179)\end{array}$ & $\begin{array}{l}0.479^{* *} \\
(0.215)\end{array}$ \\
\hline Post March $15 \times$ Local demonstration $=1 \times$ Pro-Bolsonaro $=1$ & $\begin{array}{r}0.860^{* * *} \\
(0.073)\end{array}$ & $\begin{array}{c}1.233^{* * *} \\
(0.091)\end{array}$ & $\begin{array}{c}0.891^{* * *} \\
(0.081)\end{array}$ & $\begin{array}{c}0.576^{* * *} \\
(0.057)\end{array}$ \\
\hline Observations & 224,342 & 224,342 & 224,342 & 224,342 \\
\hline R Squared & 0.70 & 0.83 & 0.82 & 0.74 \\
\hline Municipality FE & $\checkmark$ & $\checkmark$ & $\checkmark$ & $\checkmark$ \\
\hline Commuting zone $\mathrm{x}$ Time FE & $\checkmark$ & $\checkmark$ & $\checkmark$ & $\checkmark$ \\
\hline Pre-demo number of cases $\mathrm{x}$ Time FE & $\checkmark$ & $\checkmark$ & $\checkmark$ & $\checkmark$ \\
\hline Population Density x Time FE & $\checkmark$ & $\checkmark$ & $\checkmark$ & $\checkmark$ \\
\hline
\end{tabular}




\section{Pre-treatment questions - study 2}

Strength of political social identity: based on the reported political identity of respondents, we ask: (1) "when people criticize [Bolsonaristas] [anti-Bolsonaristas], it feels like a personal insult", (2) "I have a lot in common with other [Bolsonaristas] [anti-Bolsonaristas]", (3) "When I meet someone who [supports] [opposes] Bolsonaro, I feel connected with this person", (4) "When people [praise] [condemn] Bolsonaro, it makes me feel good." Responses are recorded in a four-point scale ranging from "completely agree" to "completely disagree".

Cognitive resources test: (1) If you're running a race and you pass the person in second place, what place are you in? [intuitive answer: first; correct answer: second]; (2) Emilia's father has three daughters. The first two are named Margarida and Rosa. What is the third daughter's name? [intuitive answer: Violeta; correct answer: Emilia]; (3) a bat and a ball cost $\mathrm{R} \$ 1.10$ in total. The bat costs a dollar more than the ball. How much does the ball cost? [intuitive answer: 10 cents; correct answer: 5 cents]; (4) A man buys a pig for $\mathrm{R} \$ 60$, sells it for $\mathrm{R} \$ 70$, buys it back for $\mathrm{R} \$ 80$, and sells it finally for $\mathrm{R} \$ 90$. How much has he made? [intuitive answer: $\mathrm{R} \$ 10$; correct answer: $\mathrm{R} \$ 20$ ]

Item 2 is adapted from the original question "Emily's father has three daughters. The first two are named April and May. What is the third daughter's name? (intuitive answer: June; correct answer: Emily)". We could not use the original question because in Brazil it is not common to name children after months.

For more information about other pre-treatment questions (namely, batteries on: general support for Bolsonaro, trust in science, political knowledge and socio-demographics, see PAP at https://osf.io/39ajw/?view_only=2bf90b93064a47bcb81813a3c5362080).

Attention check Before running the experiment, we ask the following attention check (adapted from Campello and Zucco Jr, Campello and Zucco Jr): "Some people read newspapers or watch the news frequently. Others do not read newspapers or watch the news. 
That's the way it is everywhere, but we just want to make sure you're reading the questions until the end. Ignore the following question, select the "other value" option and write the number 5 in the space provided next to that option. Please indicate how often do you read newspapers or watch the news?". Those who did not follow the text's instructions are screened out of the survey. ${ }^{2}$

\section{Filler}

Spend 30 seconds writing as many words as you can that start with the letter A" [Text box ]

\section{Treatments and outcome - study 2}

The first experiment is about an unapproved experimental treatment for COVID-19: the EXO-CD24 nasal spray. More specifically, respondents are asked to read the following text:

\footnotetext{
${ }^{2}$ We accept respondents that selected "other" and wrote in the dedicated text box any string containing: "5", "cinco" (five), "CINCO" (FIVE) or "Cinco" (Five). About $51 \%$ of the respondents did not pass the attention check and were screened out. We proceeded with data collection until we reached the necessary number of completes, which according to our pre-registered power analysis was about 3,000.
} 


\section{EXPERIMENT 1: Nasal Spray}

A preliminary study investigated the effectiveness of the EXO-CD24 nasal spray, previously used to treat cancer, in treating patients with severe forms of COVID-19. This study shows that out of 35 patients hospitalized with COVID-19 who were treated with the spray, 31 improved their health and were able to return home about four days after starting the treatment. Scientists caution that this preliminary study is unreliable due to the small number of participants and the lack of randomized, double-blind trials.

[Some Brazilian politicians are] [President Jair Bolsonaro is] very optimistic about using the EXO-CD24 nasal spray to treat COVID-19. [One of them] [President Jair Bolsonaro] said that the spray was $100 \%$ effective in curing severe cases of COVID-19 and that it appears to be a miraculous product.

At the end of this vignette, we ask an attention check where we ask respondents to indicate whether the following statement is true or false: "a study analyzing the effectiveness of the EXO-CD24 nasal spray to treat COVID-19 was carried out".

To test whether Bolsonaro's cues have an impact in this setting, we present the following statements and provide a seven-point Likert-type scale to access respondents level of agreement:

1. The EXO-CD24 Nasal Spray seems an excellent treatment option for COVID-19.

2. The national health surveillance agency (ANVISA) must authorize the experimental use of the EXO-CD24 nasal spray to treat COVID-19.

3. If a friend or relative were hospitalized with severe COVID-19, I would very much like him or her to be treated with EXO-CD24 nasal spray. 
4. I would be willing to participate in a potential scientific study carried out in Brazil as part of the approval process for the EXO-CD24 nasal spray for COVID-19 treatment.

The second setting is a campaign to encourage social distancing and mask use in Brazil. Respondents are asked to read the following text:

\section{EXPERIMENT 2: Campaign about non-pharmaceutical interventions}

Scientists say that in the current COVID-19 situation in Brazil, it is very important to wash your hands with soap and water or use alcohol gel, avoid gatherings, keep a safe distance from other people and wear a mask even if you are fully vaccinated.

Last month, a campaign to inform the population about how to be protected against COVID19 was launched. This campaign was launched thanks to the approval of [some Brazilian politicians] [President Jair Bolsonaro] in response to a new highly contagious variant of COVID-19. The first message in this campaign states:

"Even though more and more people are getting their vaccines against COVID-19, it is very important that we continue to take care of each other. Therefore, always wash your hands with soap and water or use alcohol gel, avoid gatherings, keep a safe distance from other people and wear a mask".

At the end of this text, we perform an attention check where we ask respondents a factual question about the text they just read. This is a true or false question about the following statement: "Last month, a campaign was launched to inform the public about the importance of sanitizing hands, avoiding crowding, and wearing a mask." The outcome questions of this experiment are as follows (responses are provided in a seven-point Likert-type scale on level of agreement):

1. On a scale where 1 represents "strongly disagree" and 7 "strongly agree", to what extent do you agree with the carrying out of the campaign described in the text? 
2. Wearing a mask helps to prevent the spread of COVID-19.

3. Hand sanitizing helps to prevent the spread of COVID-19.

4. Keeping a safe distance from one another helps to prevent the spread of COVID-19.

5. I will wear a mask whenever I leave home.

6. I will sanitize my hand whenever I can.

7. I will keep a safe distance from other people whenever I can.

8. I will leave home only when necessary.

9. I will not join social events.

\section{Descriptive statistics - study 2}

Table A.7: Descriptive statistics for cue and control conditions

\begin{tabular}{lcccc}
\hline \hline & & & & \\
& All & Cue & Control & Diff. \\
\hline Gender: Woman & 0.47 & 0.47 & 0.47 & -0.00 \\
Race: White & 0.58 & 0.58 & 0.59 & 0.01 \\
Education: more than high school & 0.76 & 0.75 & 0.77 & 0.01 \\
Age: 40 or more & 0.46 & 0.47 & 0.45 & -0.01 \\
Bolsonaro supporter & 0.42 & 0.42 & 0.41 & -0.01 \\
Political knowldge & 0.85 & 0.85 & 0.85 & -0.00 \\
Cognitive resources & 0.47 & 0.47 & 0.47 & -0.00 \\
Trust in scientists & 0.75 & 0.75 & 0.75 & -0.00 \\
General support for Bolsonaro & -0.01 & 0.00 & -0.02 & -0.02 \\
Political index strenght (Bolsonaro opponents) & 0.58 & 0.57 & 0.58 & 0.01 \\
Political index strenght (Bolsonaro supporters) & 0.52 & 0.52 & 0.52 & -0.00 \\
Support for nasal spray & -0.00 & -0.05 & 0.05 & $0.11^{* * *}$ \\
Support for social distancing & -0.00 & 0.03 & -0.03 & -0.06 \\
\hline N & 2,997 & 1,505 & 1,492 & \\
\hline \hline
\end{tabular}




\section{Triple interactions - study 2}

Table A.8: Triple interaction

\begin{tabular}{lcccc}
\hline \hline & Support for nasal spray & \multicolumn{2}{c}{ Support for social distancing } \\
\hline & $\begin{array}{c}\text { Bolsonaro } \\
\text { opponents } \\
(1)\end{array}$ & $\begin{array}{c}\text { Bolsonaro } \\
\text { supporters }\end{array}$ & $\begin{array}{c}\text { Bolsonaro } \\
\text { opponents }\end{array}$ & $\begin{array}{c}\text { Bolsonaro } \\
\text { supporters } \\
(4)\end{array}$ \\
\hline Below p50 cog. resources $\times$ Pol. social id $\times$ Cue & $-0.358^{* *}$ & 0.193 & $-0.182^{*}$ & 0.241 \\
& $(0.169)$ & $(0.229)$ & $(0.108)$ & $(0.317)$ \\
Above p50 cog. resources $\times$ Pol. social id $\times$ Cue & -0.265 & $0.619^{* *}$ & $-0.235^{*}$ & $0.862^{* *}$ \\
& $(0.211)$ & $(0.313)$ & $(0.135)$ & $(0.434)$ \\
\hline N & 1753 & 1244 & 1751 & 1243 \\
R2 & -0.325 & 0.458 & 0.306 & -0.431 \\
\hline \hline
\end{tabular}

Note: (i) Estimations include controls for gender, race, religion, State of residence, age, and date when individuals answered the survey (ii) Estimations also include controls for an indicator for below p50 of cognitive resources, an indicator for cue condition, the political social identity index, and interactions between these variables ; (iii) ${ }^{*} p<0.10,{ }^{* *} p<0.05,{ }^{* * *} p<0.001$ 


\section{Other pre-registered analysis - study 2}

Table A.9: Strength of Political Identity as Moderator

\begin{tabular}{lcccc}
\hline \hline & Support for nasal spray & \multicolumn{2}{c}{ Support for social distancing } \\
& $\begin{array}{c}\text { Bolsonaro } \\
\text { opponents } \\
(1)\end{array}$ & $\begin{array}{c}\text { Bolsonaro } \\
\text { supporters } \\
(2)\end{array}$ & $\begin{array}{c}\text { Bolsonaro } \\
\text { opponents } \\
(3)\end{array}$ & $\begin{array}{c}\text { Bolsonaro } \\
\text { supporters } \\
(4)\end{array}$ \\
\hline Cue nasal spray $\times$ Below p50 pol. identity & $-0.153^{* * *}$ & -0.015 & & $(0.067)$ \\
& $(0.053)$ & & \\
Cue nasal spray $\times$ Above p50 pol. identity & $-0.276^{* * *}$ & 0.058 & & $-0.404^{* * *}$ \\
& $(0.063)$ & $(0.072)$ & & $(0.099)$ \\
Above p50 pol. identity & $-0.166^{* * *}$ & $0.330^{* * *}$ & $0.132^{* * *}$ & 0.080 \\
& $(0.059)$ & $(0.071)$ & $(0.037)$ & $(0.094)$ \\
Cue campaign $\times$ Below p50 pol. identity & & & 0.031 & $0.227^{* *}$ \\
Cue campaign $\times$ Above p50 pol. identity & & & $(0.034)$ & $(0.100)$ \\
& & & $(0.040)$ & 1239 \\
N & 1752 & 1240 & 1750 & -0.431 \\
R2 & -0.325 & 0.458 & 0.306 & 0.114 \\
\hline \hline
\end{tabular}

Note: (i) Estimations include controls for gender, race, religion, State of residence, age, and date when individuals answered the survey; (ii) ${ }^{*} p<0.10,{ }^{* *} p<0.05,{ }^{* * *} p<0.001$ 
Table A.10: Trust in Science as Moderator

\begin{tabular}{|c|c|c|c|c|}
\hline & \multicolumn{2}{|c|}{ Support for nasal spray } & \multicolumn{2}{|c|}{ Support for social distancing } \\
\hline & $\begin{array}{c}\text { Bolsonaro } \\
\text { opponents } \\
(1)\end{array}$ & $\begin{array}{c}\text { Bolsonaro } \\
\text { supporters } \\
(2)\end{array}$ & $\begin{array}{c}\text { Bolsonaro } \\
\text { opponents } \\
(3)\end{array}$ & $\begin{array}{c}\text { Bolsonaro } \\
\text { supporters } \\
(4)\end{array}$ \\
\hline Cue nasal spray $\times$ Below p50 trust in science & $\begin{array}{c}-0.244^{* * *} \\
(0.063)\end{array}$ & $\begin{array}{c}0.050 \\
(0.062)\end{array}$ & & \\
\hline Cue nasal spray $\times$ Above p50 trust in science & $\begin{array}{c}-0.172^{* * *} \\
(0.054)\end{array}$ & $\begin{array}{l}-0.019 \\
(0.087)\end{array}$ & & \\
\hline Above p50 trust in science & $\begin{array}{l}-0.055 \\
(0.059)\end{array}$ & $\begin{array}{c}0.104 \\
(0.075)\end{array}$ & $\begin{array}{c}0.188^{* * *} \\
(0.037)\end{array}$ & $\begin{array}{c}0.651^{* * *} \\
(0.101)\end{array}$ \\
\hline Cue campaign $\times$ Below p50 trust in science & & & $\begin{array}{l}0.076^{*} \\
(0.039)\end{array}$ & $\begin{array}{c}0.218^{* * *} \\
(0.083)\end{array}$ \\
\hline Cue campaign $\times$ Above p50 trust in science & & & $\begin{array}{l}-0.060^{*} \\
(0.034)\end{array}$ & $\begin{array}{c}0.027 \\
(0.116)\end{array}$ \\
\hline $\mathrm{N}$ & 1752 & 1240 & 1750 & 1239 \\
\hline Mean Dep. Var. & -0.325 & 0.458 & 0.306 & -0.431 \\
\hline $\mathrm{R} 2$ & 0.065 & 0.055 & 0.056 & 0.141 \\
\hline
\end{tabular}

Note: (i) Estimations include controls for gender, race, religion, State of residence, age, and date when individuals answered the survey; (ii) ${ }^{*} p<0.10,{ }^{* *} p<0.05,{ }^{* * *} p<0.001$ 
Table A.11: Cognitive resources as Moderator

\begin{tabular}{lcccc}
\hline \hline & Support for nasal spray & \multicolumn{2}{c}{ Support for social distancing } \\
\hline & $\begin{array}{c}\text { Bolsonaro } \\
\text { opponents } \\
(1)\end{array}$ & $\begin{array}{c}\text { Bolsonaro } \\
\text { supporters } \\
(2)\end{array}$ & $\begin{array}{c}\text { Bolsonaro } \\
\text { opponents } \\
(3)\end{array}$ & $\begin{array}{c}\text { Bolsonaro } \\
\text { supporters } \\
(4)\end{array}$ \\
\hline Cue nasal spray $\times$ Below p50 cog. resources & $-0.216^{* * *}$ & -0.005 & & \\
& $(0.046)$ & $(0.056)$ & & -0.043 \\
Cue nasal spray $\times$ Above p50 cog. resources & $-0.148^{*}$ & 0.153 & & $(0.129)$ \\
& $(0.090)$ & $(0.114)$ & -0.040 & 0.113 \\
Above p50 cog. resources & -0.083 & -0.085 & $(0.046)$ & $0.077)$ \\
Cue campaign $\times$ Below p50 cog. resources & $(0.073)$ & $(0.094)$ & 0.000 & $(0.157)$ \\
Cue campaign $\times$ Above p50 cog. resources & & & $(0.029)$ & 1239 \\
& & & 0.004 & -0.431 \\
N & & & $(0.057)$ & 0.097 \\
Mean Dep. Var. & -0.325 & 0.458 & 0.306 & 0.042 \\
\hline \hline
\end{tabular}

Note: (i) Estimations include controls for gender, race, religion, State of residence, age, and date when individuals answered the survey; (ii) ${ }^{*} p<0.10,{ }^{* *} p<0.05,{ }^{* * *} p<0.001$ 
Table A.12: Political Knowledge as Moderator

\begin{tabular}{lcccc}
\hline \hline & Support for nasal spray & \multicolumn{2}{c}{ Support for social distancing } \\
\hline & $\begin{array}{c}\text { Bolsonaro } \\
\text { opponents } \\
(1)\end{array}$ & $\begin{array}{c}\text { Bolsonaro } \\
\text { supporters } \\
(2)\end{array}$ & $\begin{array}{c}\text { Bolsonaro } \\
\text { opponents } \\
(3)\end{array}$ & $\begin{array}{c}\text { Bolsonaro } \\
\text { supporters } \\
(4)\end{array}$ \\
\hline Cue nasal spray $\times$ Below p50 pol. knowledge & $-0.216^{* * *}$ & 0.046 & & \\
& $(0.058)$ & $(0.074)$ & & $-0.497^{* * *}$ \\
Cue nasal spray $\times$ Above p50 pol. knowledge & $-0.182^{* * *}$ & 0.011 & & $(0.102)$ \\
& $(0.057)$ & $(0.069)$ & 0.046 \\
Above p50 pol. knowledge & $-0.152^{* *}$ & 0.075 & 0.001 & $(0.100)$ \\
& $(0.060)$ & $(0.075)$ & $(0.038)$ & $0.200^{* *}$ \\
Cue campaign $\times$ Below p50 pol. knowledge & & & -0.001 & $(0.094)$ \\
Cue campaign $\times$ Above p50 pol. knowledge & & & $(0.037)$ & 1239 \\
& & & $(0.036)$ & -0.431 \\
N & 1752 & 1240 & 1750 & 0.120 \\
Mean Dep. Var. & -0.325 & 0.458 & 0.306 & 0.041 \\
\hline \hline
\end{tabular}

Note: (i) Estimations include controls for gender, race, religion, State of residence, age, and date when individuals answered the survey; (ii) ${ }^{*} p<0.10,{ }^{* *} p<0.05,{ }^{* * *} p<0.001$ 
Table A.13: Triple interaction - General support for Bolsonaro instead of Pol. social id.

\begin{tabular}{|c|c|c|c|c|}
\hline & \multicolumn{2}{|c|}{ Support for nasal spray } & \multicolumn{2}{|c|}{ Support for social distancing } \\
\hline & $\begin{array}{c}\text { Bolsonaro } \\
\text { opponents } \\
\text { (1) }\end{array}$ & $\begin{array}{c}\text { Bolsonaro } \\
\text { supporters } \\
(2)\end{array}$ & $\begin{array}{c}\text { Bolsonaro } \\
\text { opponents } \\
(3)\end{array}$ & $\begin{array}{c}\text { Bolsonaro } \\
\text { supporters } \\
(4)\end{array}$ \\
\hline Below p50 cog. resources $\times$ General support for Bolsonaro $\times$ Cue & $\begin{array}{c}0.128 \\
(0.134)\end{array}$ & $\begin{array}{c}0.031 \\
(0.089)\end{array}$ & $\begin{array}{l}-0.006 \\
(0.087)\end{array}$ & $\begin{array}{c}0.105 \\
(0.121)\end{array}$ \\
\hline Above p50 cog. resources $\times$ General support for Bolsonaro $\times$ Cue & $\begin{array}{c}0.063 \\
(0.164)\end{array}$ & $\begin{array}{l}0.272^{* *} \\
(0.127)\end{array}$ & $\begin{array}{c}0.020 \\
(0.106)\end{array}$ & $\begin{array}{l}0.413^{* *} \\
(0.173)\end{array}$ \\
\hline $\mathrm{N}$ & 1752 & 1244 & 1750 & 1243 \\
\hline Mean Dep. Var. & -0.325 & 0.458 & 0.306 & -0.431 \\
\hline $\mathrm{R} 2$ & 0.113 & 0.089 & 0.041 & 0.152 \\
\hline
\end{tabular}

Note: (i) Estimations include controls for gender, race, religion, State of residence, age, and date when individuals answered the survey (ii) Estimations also include controls for an indicator for below p50 of cognitive resources, an indicator for cue condition, the general support for Bolsonaro, and interactions between these variables; (iii) ${ }^{*} p<0.10,{ }^{* *} p<0.05,{ }^{* * *} p<0.001$ 

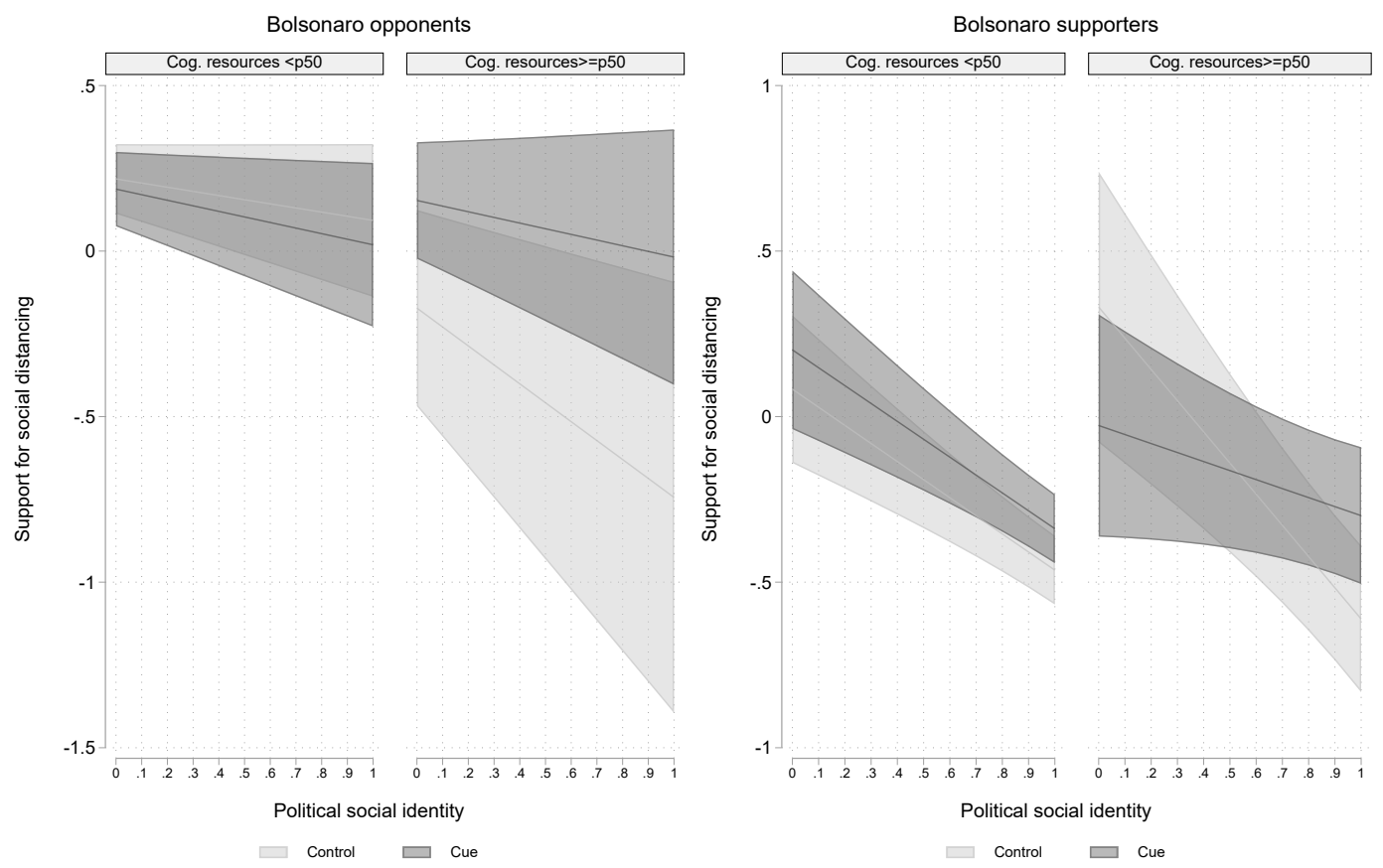

Figure A.4: Heterogeneity by general support for Bolsonaro and cognitive resources - Social distancing

Notes: (i) Graphs based on table A.13, (ii) The figure presents the predicted values for control and treatment groups by level of cognitive resources and strength of political social identity with $95 \%$ CIs. 

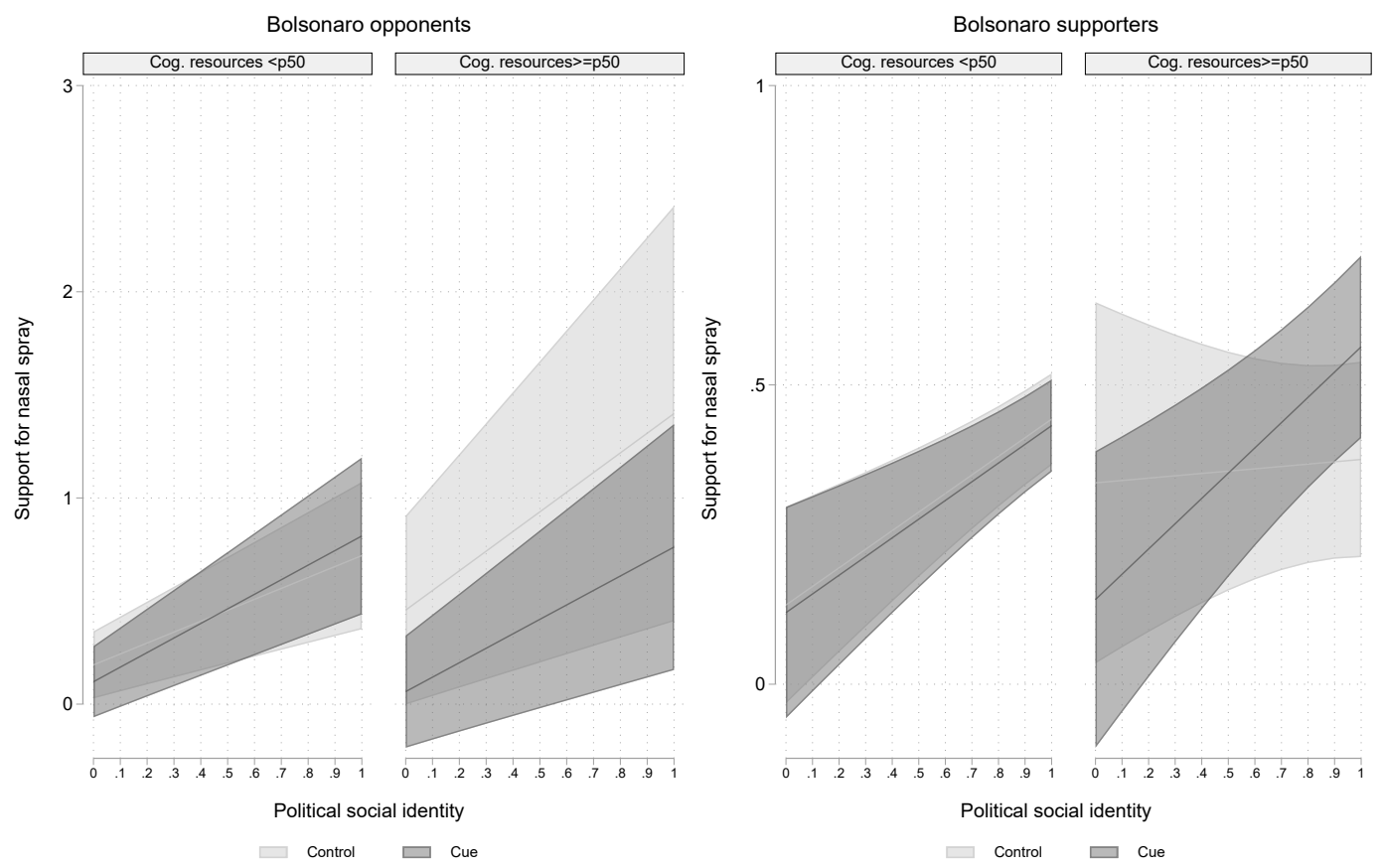

Figure A.5: Heterogeneity by general support for Bolsonaro and cognitive resources - Nasal spray

Notes: (i) Graphs based on table A.13, (ii) The figure presents the predicted values for control and treatment groups by level of cognitive resources and strength of political social identity with $95 \%$ CIs.

\section{References}

Alonso, W. J., C. Viboud, L. Simonsen, E. W. Hirano, L. Z. Daufenbach, and M. A. Miller (2007). Seasonality of influenza in brazil: a traveling wave from the amazon to the subtropics. American journal of epidemiology 165(12), 1434-1442.

Campello, D. and C. Zucco Jr. Commodity price shocks and misattribution of responsibility for the economy: observational and experimental evidence. Unoublished manuscript.

Ministério da Saúde (2019). 21 a campanha nacional de vacinação contra a influenza atualização. Technical report.

Sato, A. P. S., J. L. F. Antunes, R. F. Moura, F. B. de Andrade, Y. A. O. Duarte, and 
M. L. Lebrão (2015). Factors associated to vaccination against influenza among elderly in a large brazilian metropolis. PloS one 10(4), e0123840. 